Fall 2005

\title{
Chinese Regionalism and the 2004 ASEAN-China Accord: The WTO and Legalized Trade Distortion
}

M. Ulric Killion

Follow this and additional works at: https://scholarship.law.unc.edu/ncilj

\section{Recommended Citation}

M. U. Killion, Chinese Regionalism and the 2004 ASEAN-China Accord: The WTO and Legalized Trade Distortion, 31 N.C. J. INT'L L. 1 (2005).

Available at: https://scholarship.law.unc.edu/ncilj/vol31/iss1/1

This Article is brought to you for free and open access by Carolina Law Scholarship Repository. It has been accepted for inclusion in North Carolina Journal of International Law by an authorized editor of Carolina Law Scholarship Repository. For more information, please contact law_repository@unc.edu. 
Chinese Regionalism and the 2004 ASEAN-China Accord: The WTO and Legalized Trade Distortion

Cover Page Footnote

International Law; Commercial Law; Law 


\title{
Chinese Regionalism and the 2004 ASEAN-China Accord: The WTO and Legalized Trade Distortion
}

\author{
M. Ulric Killiont
}

\begin{abstract}
The issue presented is whether Chinese regionalism (quyu zhuyi), or "new regionalism" (xin quyu zhuyi), poses a threat to the multilateral world trading system. The question directly relates to the recent 2004 ASEAN-China accord, which proposes to establish the world's largest free trade area (FTA). Regionalism promoted by exclusionary motivations, such as political considerations, tends to produce trade distortion, and is welfarereducing. An exclusionary trading area of such magnitude may pose a threat to multilateral world trade. In such an event, trade distortion may result in great harm to the global economy, producing disastrous economic and social consequences worldwide. This article examines the consequences that may flow from the recent 2004 ASEAN-China accord and adequacy of the World Trade Organization (WTO) rules governing FTAs. It also analyzes Chinese regionalism, trade distortion versus trade creation, and finally, whether the 2004 ASEAN-China accord threatens the WTO and multilateral trade, especially in the wake of the January 1, 2005, termination of the WTO Agreement on Textiles and Clothing (ATC).

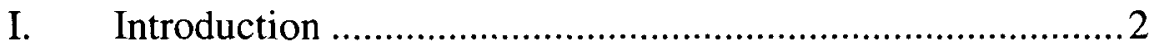

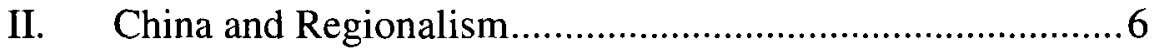

A. The 2004 ASEAN-CHINA Accord .............................6

B. The Termination of the ATC ........................................ 9

C. The Political Economy of China .................................. 19

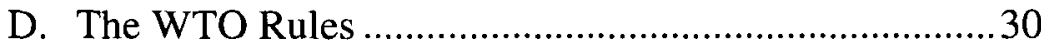

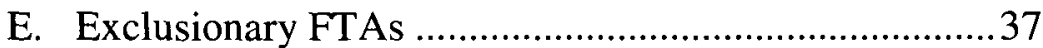

III. China-Led Regionalism ..........................................52

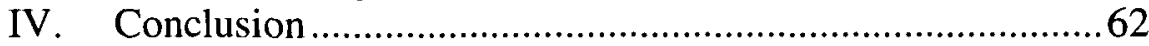

$\dagger$ B.S. Econ., Doctor of Law, J.D., Visiting Professor of International Law, Shanghai International Studies University. 


\section{Introduction}

The emergence of the People's Republic of China (China) as a major economic and political power presents a significant challenge to the Association of Southeast Asian Nations' (ASEAN) regionalism and to the multilateral world trading system. ${ }^{1}$ Having joined the World Trade Organization (WTO), China now appears determined, for political reasons, to use free trade agreements (FTAs) to consolidate an Asian regional trading system. $^{2}$ On November 29, 2004, China joined ASEAN in an agreement that established regional cooperation between the signing countries. ${ }^{3}$ This agreement paved the way for establishing the world's largest free trade zone, composed of 1.7 billion consumers, and demonstrated a Chinese model for regionalism (quyu zhuyi), if not a "new regionalism" (xin quyu zhuyi). ${ }^{4}$

Regionalism based on the European Union model, or regional agreements comprising developed economies and developing economies, such as the North American Free Trade Agreement (NAFTA), are successful models of integration. ${ }^{5}$ In these

1 See China More Mature in Diplomacy, ChINA DAILY, Dec. 16, 2004; see also ASEAN.org, Association of Southeast Asian Nations, Overview, http://www.aseansec.org/64.htm [hereinafter ASEAN] ("ASEAN was established on 8 August 1967 in Bangkok by the five original Member Countries, namely, Indonesia, Malaysia, Philippines, Singapore, and Thailand. Brunei Darussalam joined on 8 January 1984, Vietnam on 28 July 1995, Laos and Myanmar on 23 July 1997, and Cambodia on 30 April 1999.").

2 See Naoko Munakata, The Impact of the Rise of China and Regional Economic Integration in Asia-A Japanese Perspective, U.S.-China Economic and Security Review Commission Hearing on China's Growth as a Regional Economic Power, Dec. 4, 2003, Washington, D.C., http://www.uscc.gov/hearings/2003hearings/written_testimonies/ 031204bios/naokmunakata.htm; see also Decision, Accession of the People's Republic of China, W/L 432 (Nov. 10, 2001). The Protocol was accepted by the Government of the People's Republic of China on Nov. 11, 2001, and will come into force on December 11, 2001. Pursuant to paragraph 1, Part 1 of the Protocol, China will become a member of the World Trade Organization on December 11, 2001. Accession of the People's Republic of China, supra.

3 See Deal Forms Free-trade Megazone, China, ASEAN Sign Landmark Accord, Shanghal DaILY, Nov. 30, 2004 [hereinafter Deal Forms Free-trade Megazone].

4 Id.

5 See Organisation for Economic Co-operation and Development [OECD], Regional Integration Agreement, OECD Publication, Jan. 1, 2001, 
instances, the economic benefits of integration far outweighed the incidental economic costs of any secondary political considerations that may have motivated integration. ${ }^{6}$ Conversely, China now proposes a model of regional integration that is primarily motivated by political considerations and threatens multilateral trade. ${ }^{7}$

Following accession to the WTO, or more accurately, an agreement on terms of accession with the United States in 1999, China decided to use FTAs as a policy tool. ${ }^{8}$ This policy directed its focus on making ASEAN China's first FTA partner. ${ }^{9}$ In November 2000 during the fourth ASEAN Informal Summit, China proposed the creation of an FTA between China and ASEAN. $^{10}$ In October 2001, China and ASEAN completed a feasibility study for an FTA. " One month later, it was determined that an ASEAN-China FTA would be established within ten

http://www.oecd.org/dataoecd/39/37/1923431.pdf. "The most successful regional integration to date has been the EU." Political objectives did in part motivate the formation of the EU. Id. at 11. "However, the political effects can sometimes be unexpected or opposite of the aspirations, as when regional preferences create such unfair redistributions that they provoke conflict." $I d$. at 28 .

$6 \mathrm{Id}$.

7 See, e.g., Sheng Lijun, China-ASEAN Free Trade Area: Origins, Developments and Strategic Motivations 13 (Inst. of Se. Asian Studies, Working Paper: International Politics \& Security Issues Series No. 1, 2003), http://www.iseas.edu.sg/ipsi12003.pdf ("Apparently China is employing this regional integration or regionalism to dilute U.S. strategic unilateralism in East Asia."); Richard Baldwin, Problems and Prospects for East Asian Regionalism: A Comparison with Europe, Speech at Research Institute of Economics and Trade Brown Bag Lunch Seminar No. 163 (Jan. 31, 2003), http://www.rieti.go.jp/en/events/bbl/03013101.html ("The lesson for Asia today is that you cannot have two FTA blocs near each other. Once regional integration starts, it is hard to resist. As an analogy, Japan's position is like the UK's position in Europe in the 1950s: it is the biggest market but a reluctant regionalist. China is like France was because China is triggering integration for political reasons."). note 2 .

8 China was primarily motivated by politics rather than economics. Naoko, supra

9 Id.

10 John Wong \& Sarah Chan, China-ASEAN Free Trade Arrangement: Opportunities and Challenges, proceedings of the International Seminar on ChinaASEAN Trade, Investment and Development Cooperation (6-7 June 2002), organized jointly by the Ministry of Foreign and Economic Cooperation, and Yunnan Provincial People's Government, Kuoming, China, 217-235 (Sept. 2002), http://www.ecdc.net.cn/ newindex/chinese/page/sitemap/focus/proceedings/englishg/part\%20two/08.htm.

11 Naoko, supra note 2. 
years. $^{12}$ The parties signed the Framework Agreement on ASEAN-China Economic Cooperation in November 2002 to establish an FTA by 2010 for older ASEAN members and by 2015 for newer ASEAN members. ${ }^{13}$ ASEAN was chosen as China's first FTA partner for the purpose of addressing perceived Chinese threats to the economic and security interests of ASEAN nations. ${ }^{14}$ The overriding diplomatic and political considerations manifest themselves in China's willingness, via an FTA, to allow ASEAN economies to capitalize on its growth. ${ }^{15}$ One such example is the initial October 2003 elimination of tariffs on fruits and vegetables. ${ }^{16}$

An ASEAN-China FTA would comprise developing economies, and the inclusion of such economies would provide a WTO safety net for the parties. ${ }^{17}$ In the event negotiations became difficult, China and ASEAN could avail themselves of the enabling clause for WTO developing members. ${ }^{18}$ The enabling clause permits "derogations to the most-favored nation (nondiscrimination) treatment in favor of developing countries. In particular, its paragraph 2(c) permits preferential arrangements among developing countries in goods trade." 19 Thus, their FTA would be exempt from the strict rule covering "substantially all the trade," a rule governing an FTA with a developed country member. ${ }^{20}$ The latter addresses a much-debated controversy concerning a loophole in the WTO Rules: Article XXIV, which

$\begin{array}{ll}12 & \text { Id } \\ 13 & \text { Id } \\ 14 & \text { Id } \\ 15 & \text { Id } \\ 16 & \text { Id }\end{array}$

$16 \mathrm{Id}$.

17 See T. N. Srinivasan, Preferential Trade Agreements with Special Reference to Asia (Nov. 2001) (presented at the Asian Economic Outlook Workshop, Manila, Nov. 2001) (on file with Yale University), http://www.econ.yale.edu/ srinivas/PrefTrade Agreements.pdf.

18 GATT 1947, Decision of 28 Nov. 1979 (L/4903) [hereinafter Enabling Clause], http://www.wto.org/english/docs_e/legal_e/enabling1979_e.htm.

19 Id.

20 Srinivasan, supra note 17; see also General Agreement on Tariffs and Trade [GATT], pt. III, art. XXIV: Territorial Application-Frontier Traffic-Customs Unions and Free-trade Areas, paras. 5 and 8 , http://www.wto.org/english/docs_e/legal_e/ gatt47_02_e.htm [hereinafter Free Trade Area Provision]. 
governs FTAs. $^{21}$

China's pre-accession decision to employ FTAs as a policy tool eventually culminated in the 2004 ASEAN-China Accord. ${ }^{22}$ The accord, which is the world's largest proposed FTA, presents the issue of whether there is a distinguishable Chinese model of regionalism and what consequences may ensue from that model. The potential consequences vary, from threatening trade and investment liberalization, to enhancing possible worldwide disastrous economic and social fallout resulting from the January 1, 2005, termination of the WTO Agreement on Textiles and Clothing (ATC). ${ }^{23}$

Part II of this Article presents an introduction to the 2004 ASEAN-China accord and its relevant terms and goals, followed by an introduction to the consequences ensuing from the January 1, 2005 termination of the ATC. Then this Article introduces the political economy environment of China, the WTO rules governing FTAs, the goals of the WTO, and the problems attendant to a growth of regional trading arrangements, such as FTAs. It further explains the problem associated with FTAs motivated by political rather than economic considerations in terms of both trade creation versus trade diversion and welfare enhancement versus welfare reduction.

Part III of the Article analyzes the 2004 ASEAN-China accord in terms of FTAs motivated by political considerations versus economic considerations, trade creation versus trade diversion, the WTO rules governing FTAs, and the consequences, if any, that

21 Free Trade Area Provision, supra note 20, at para. 5; see also ARVIND Panagariya, Regionalism in Trade Policy: Essays on Preferential Trading 47 (1999). Free Trade Areas (FTAs) can be grouped in three different WTO categories: Article XXIV arrangements involving FTAs and Custom Unions (CUs), Enabling Clause arrangements limited to developing countries and permitting partial preferences, and Generalized System of Preferences (GSP) arrangements permitted via a grant of an exception to Article 1. PANAGARIYA supra.

22 Naoko, supra note 2 (In the FTA race, "China's moves are driven by a political agenda of reassuring ASEAN and expanding its political influence in the region.").

23 See Press Brief, WTO, Textiles (1996), http://www.wto.org/english/thewto_e/ minist_e/min96_e/textiles.htm. The ATC replaced the Multi-fibre Agreement (MFA), which was in force from 1974 to 1994. Id. See also WTO.org, Legal Texts: The WTO Agreements, WTO Legal Texts: The Uruguay Round Agreements, http://www.wto.org/english/docs_e/legal_e/ursum_e.htm\#cAgreement [hereinafter ATC]. 
attach to the January 1, 2005 termination of the ATC. This Article concludes with a discussion of the adequacy of WTO rules governing FTAs, the growth of China-led regionalism, whether Chinese regionalism presents a model of integration distinguishable from Western models, and the consequences of Chinese regionalism, which may include a threat to multilateral trade and the WTO.

\section{China and Regionalism}

\section{A. The 2004 ASEAN-CHINA Accord}

At the Tenth ASEAN Summit in Vientiane, Laos on November 29, 2004, China and ASEAN signed a landmark agreement to cut tariffs, which was a substantial step toward creating the world's largest FTA by $2010 .{ }^{24}$ The most prominent of the series of agreements and mechanisms produced by the summit are the Agreement on Trade in Goods, the Framework Agreement on Comprehensive Economic Cooperation between ASEAN and China, and the Agreement on Dispute Settlement Mechanism. ${ }^{25}$ An important aspect of this accord is that it requires the two regions to begin building a massive tariff-free market over the next five years in an area comprising close to two billion people. $^{26}$

24 See Sun Shangwu, ASEAN Deal Hailed as Milestone for Regional Co-operation, China DaILY, Nov. 30, 2004.

25 See Sun Shangwu, ASEAN Links Push Free Trade, China Daily, Nov. 29, 2004.

26 Id. See also 10th ASEAN Summit.gov, ASEAN Overview (2004), paras. 10-11, http://www.10thaseansummit.gov.la/asean_view.htm [hereinafter 10th ASEAN Summit].

10. In realising the ASEAN Free Trade Area (AFTA), $98.62 \%$ of the products in the CEPT Inclusion List (IL) of ASEAN-6 have been brought down to the 0$5 \%$ tariff range. As of September 2004, products in the IL, which continue to have tariffs of above $5 \%$ are those that have been transferred from the Sensitive Lists (SL) and General Exception Lists (GE) in 2003. Tariffs on $60.89 \%$ of the products in the IL of ASEAN-6 have been eliminated. The average tariff for ASEAN-6 under the CEPT Scheme is now down to $1.91 \%$ from $12.76 \%$ in 1993. For the new ASEAN Member Countries (Cambodia, Laos, Myanmar and Vietnam), $79.13 \%$ of the products traded in the region have been moved into the IL and tariffs on $69.88 \%$ of these items have already been brought down within the $0-5 \%$ band.

11. Regional financial cooperation has also strengthened. The bilateral swap arrangements network under the Chiang Mai Initiative now comprises 16 agreements with a combined size of US $\$ 36.5$ billion. The Finance Ministers of 
According to Chinese sources, the establishment of this FTA will boost the development of this region, by 1.7 billion consumers, about $\$ 1.8$ trillion in gross domestic product (GDP), and $\$ 1.2$ trillion in trade volume. ${ }^{27}$ Statistics from the People's Republic of China Ministry of Commerce (MOFCOM) show that ASEAN has been China's fifth largest trade partner for eleven consecutive years. ${ }^{28}$ Trade volume hit $\$ 84.61$ billion in the first ten months of 2004, which is an increase of 35.2 percent over the same period in 2003. ${ }^{29}$ The accord between China and ASEAN is expected to build on two-way trade and surpass $\$ 100$ billion in $2004 .^{30}$ Notwithstanding a trade deficit with ASEAN, China anticipates that trade will balance out with growth in the region and the agreements are expected to create a win-win situation for economic and trade relations. ${ }^{31}$

Moreover, the significance of the 2004 ASEAN-China accord is enhanced by China's increasingly growing global trade volume.

ASEAN are also working on a series of promotional activities to attract more funds from developed capital markets outside Southeast Asia to move into ASEAN to strengthen the regional financial markets. Id.

27 Sun, supra note 25.

28 Id. People's Republic of China Ministry of Commerce (Zhonghua renmin gongheguo shangwu bu) (MOFCOM), http://english.mofcom.gov.cn/. The mandate of the MOFCOM is "to formulate development strategies, guidelines and policies of domestic and foreign trade and international economic cooperation," and other related duties.

29 Sun, supra note 25.

30 Deal Forms Free-trade Megazone, supra note 3.

31 Id.; see also Sun, supra note 25; 10th ASEAN Summit, supra note 26, paras. 79.

7. ASEAN's trade performance grew significantly in 2003. Total ASEAN exports grew by $12.12 \%$ from US $\$ 383.85$ billion in 2002 to US $\$ 430.39$ billion in 2003 . Total ASEAN imports grew by $9.51 \%$ or from US $\$ 328.11$ billion in 2002 to US $\$ 359.32$ billion in 2003.

8. Intra-ASEAN exports grew higher than the total ASEAN exports. The overall growth was $15.4 \%$ or in value term it grew from US\$86.39 billion in 2002 to US $\$ 99.7$ billion in 2003 . Intra-ASEAN imports experienced modest growth in 2003, from US\$72.23 billion in 2002 to US\$74.49 billion in 2003.

9. The United States, Japan, the European Union, China and the Republic of Korea (ROK) remained ASEAN's largest trading partners. The share of ASEAN's total trade with these countries in overall ASEAN trade in 2003 were $14.1 \%, 13.7 \%, 11.5 \%, 7.0 \%$ and $4.1 \%$, respectively. 10th ASEAN Summit, supra note 26 , at paras. $7-9$. 
In 2005, China's MOFCOM reported that in 2004 China registered a 34.7 percent surge in foreign trade with $\$ 1.15$ trillion being exchanged. $^{32}$ As a result, China became the world's third largest trading power, behind only the United States and Germany. ${ }^{33}$ However, some Chinese sources fear analysts may use these figures to promote trade protectionism and insist China is not a large or strong trading power. ${ }^{34}$ In defense of a large trade volume, these sources tout a yearly surplus of $\$ 32$ billion, which is up by 25.5 percent year-on-year, and further argue that argue that China's trade accounts for just 5.5 percent of global trade volume, its per capita trade value is roughly only one-third of the world's average, and in the first quarter of 2004 it registered a trade deficit of $\$ 8.4$ billion. ${ }^{35}$ Becoming the world's third largest trader by volume may not necessarily be commensurate with being a strong trading power. However, it is difficult to deny that the economic data, especially trade volume, enhances the potential, and maybe even the threatening aspects, of the 2004 ASEAN-China accord.

As for implementing the 2004 ASEAN-China accord, ASEAN plans to accomplish this task by strengthening economic relations and expanding trade through the establishment of FTAs and Closer Economic Partnerships (CEPs). ${ }^{36}$ A Vientiane Action Programme, which was adopted by the Tenth ASEAN Summit, calls for the ten-member group to develop strategies for attracting investment needed in order to sustain economic growth. ${ }^{37}$ In the past decades, economic growth was largely driven by foreign direct investment (FDI) and exports. ${ }^{38}$ Exports have stabilized and show signs of expanding. ${ }^{39}$ However, since the East Asian

32 See Zhang Jin, Nation Now No. 3 Global Trader, China Dally, Jan. 12, 2005; see also Zhi Ming, Large Trade Volume Itself Not a Reason for Being Content, CHINA DAILY, Jan. 13, 2005.

33 Zhang, supra note 32.

$34 \mathrm{Zhi}$, supra note 32.

35 Id.

36 Sun, supra note 24.

37 ASEAN, supra note 1.

38 Id.

39 Id. Despite the unfavorable external outlook and against the backdrop of slowdown in global foreign direct investment (FDI) flows, FDI flows to ASEAN increased by $48 \%$, up from $\$ 13.7$ billion in 2002 to $\$ 20.2$ billion in 2003 , resulting in ASEAN being one of the highest FDI growth regions. The overall improved ASEAN 
financial crisis (1997-98), ASEAN has experienced a sustained decline in FDI. ${ }^{40}$ Therefore, the action program calls for a strategy that will strengthen links and promote agreements with major trade partners such as China, Japan, South Korea, the United States, Australia, New Zealand, the European Union, and India. ${ }^{41}$

ASEAN members signed an agreement that will move them closer to forming a European Union-style single market. ${ }^{42}$ They also linked the pact for tariff-reduction to Bogor-type target dates. $^{43}$ ASEAN economic ministers called for tariffs to be abolished by 2007 for the more developed members, such as Brunei, Malaysia, Indonesia, the Philippines, Singapore, and Thailand. ${ }^{44}$ The other four members, Cambodia, Myanmar, Laos, and Vietnam, will have to abolish tariffs in sectors including autos, textiles, and electronics by $2010 . .^{45}$ In addition, the Agreement on Dispute Settlement Mechanism sets up a three-person panel of independent experts to resolve trade disputes between ASEAN and China. $^{46}$

\section{B. The Termination of the ATC}

An additional problem for global trade is that the 2004 ASEAN-China Accord came at roughly the same time as the conclusion of the WTO ATC on January $1,2005 .^{47}$ The ATC was

investment environment and strong regional economic growth and integration have increased the attractiveness of ASEAN to foreign investors. The increase in FDI flows in 2003 was the highest since 2000. 10th ASEAN Summit, supra note 26, para. 12.

40 ASEAN, supra note 1; see also 10th ASEAN Summit, supra note 26.

41 Sun, supra note 25.

42 Id.

43 See Shalendra D. Sharma, Beyond ASEAN and APEC: Towards a New AsiaPacific Economic Regionalism, E. ASIAN REV. (2002), at 37. While the APEC members signed the 1994 Bogor Declaration, the accomplishment of the Bogor goals experienced a serious setback because of the East Asian financial crisis. Id. See also Asian Pacific Economic Cooperation (APEC), Bogor, Indonesia, Nov. 15, 1994, APEC Economic Leaders' Declaration of Common Resolve, http://www.apec.org/apec/leaders_ declarations/1994.html.

44 Sun, supra note 24.

45 ASEAN Summit Stresses Integrated Region, ChINA DAILY, Nov. 30, 2004.

46 Sun, supra note 24; see also Deal Forms Free-trade Megazone, supra note 3.

47 China Apparel, Textiles Trade Reform: Unstitched by China, WTO, Oct. 22, 2004, http://www.efu.com/cn/eng/onlinesales/promotion/allround/2004-10-22/6605.htm. 
widely acknowledged as trade-distorting with the distortions having paradoxical effects. ${ }^{48}$ The ATC protected developed economy markets in that it used quotas to limit clothing imports from developing economies. ${ }^{49}$ The Uruguay Round international trade negotiations in 1994 reached an agreement that would dismantle the ATC in phases and would end when developed economies removed all quota allocations on January $1,2005 .^{50}$ Developing and less-developed economies agreed because they believed the removal of quota allocations would be beneficial. ${ }^{51}$

Termination of the ATC is producing mixed results. ${ }^{52}$ The effect of removing this trade barrier will mostly accrue first in China, then India. ${ }^{53}$ These two countries can produce clothing at lower cost than any other developing economies because of the prevalence of labor-intensive industries. ${ }^{54}$ As a result, in September 2004, nine developing and less-developed economies, Bangladesh, the Dominican Republic, Fiji, Madagascar, Mauritius, Sri Lanka, Uganda, Jamaica, and Nepal, requested the WTO's Council for Trade in Goods to conduct country-specific analyses to measure the effect of the ATC's termination. ${ }^{55}$ They sought assistance for large scale restructuring to prevent predicted impending disastrous economic and social consequences. These nations, not unlike the rest of the world, have had difficulty competing with China. ${ }^{56}$ Comparatively, China's textile and clothing imports experienced steady increases from 11 million

48 ATC, supra note 23. See also China Apparel, supra note 47.

49 China Apparel, supra note 47.

50 Id.

51 Id.

52 Id.

53 Id. See also Hildegunn Kyvik Nordås, The Global Textile and Clothing Industry post the Agreement on Textiles and Clothing 30 (WTO Secretariat, Discussion Paper No. 5, 2004), http://www.wto.org/english/res_e/booksp_e/discussion_papers5_e.pdf (predicting, based upon a simulation of the impact of phrasing out ATC quotas, that for clothing, "China and India combined take 65 percent of the export market-China triples its market share while India's market share is quadrupled. All others lose market share and the largest losses are incurred by African countries and Mexico, whose market shares decline by close to 70 percent.").

54 China Apparel, supra note 47.

55 Id.

56 Id. 
units in 1995 to 213 million units in 2003. ${ }^{57}$ Estimates have indicated the end of the ATC will result in job losses ranging from about 27 million to 31 million worldwide..$^{58}$

In June 2004, seventy-two textile and apparel groups from thirty-six countries requested in the Istanbul Declaration that the WTO extend the ATC quota-free deadline from December 31, 2004 to December 31, 2007, but their efforts failed. ${ }^{59}$ The new FTA president, Ferry den Hoed, announced the death blow to the Istanbul Declaration during a two-day mission to Geneva when the FTA delegation he headed met with representatives from the WTO, the International Labor Organization (ILO), ${ }^{60}$ and ministers and ambassadors from the larger developing countries. "The Istanbul Declaration is dead,' stated Ferry den Hoed after his discussions in Geneva." 61 The Istanbul Declaration was a failed plea to their individual governments to undertake the following actions: an emergency meeting of the WTO for the purpose of analyzing and identifying possible solutions to the pending crisis; implementation of automatic and seamless transitional safeguard mechanisms for the purpose of "massive disruptive surges of trade from a few countries;" and enactment of expedited and effective remedies to "all types of unfair trading practices employed by certain major supplying countries," including currency manipulation, state sponsored subsidies, and state non-performing loans. ${ }^{62}$

\section{Id}

$58 \mathrm{Id}$.

59 See Press Release, Foreign Trade Ass'n, Instanbul Declaration Has No Future, (June 14, 2004) (on file with the Foreign Trade Association), http://www.ftaeu.org/en/new/pmdpdf.php?site=fta\&pm_id=79.

60 International Labor Organization, http://www.ilo.org/public/english/about/ index.htm.

61 Id.

62 See Istanbul Declaration Partners in the Global Alliance for Fair Trade in Textiles and Clothing Brussels, June 17, 2004, Brussels Communiqué 1-2, http://www.deik.org.tr/genel/ 2004625141610brusselscommunique-june2004.pdf. Key provisions of the Istanbul Declaration follow.

1. Request an emergency meeting of the WTO in order to analyze and identify WTO solutions to the pending crisis associated with the expiration of textile and clothing quotas on January 1, 2005. These could include an extension of the current system, the development of a new system or the use of other WTO mechanisms. 
In the United States, the response to the termination of the ATC has been mixed and seemingly drastic. ${ }^{63}$ In October and November 2004, a United States trade and clothing industry coalition and a labor union filed nine threat-based safeguard petitions on quotas that expired on January 1, 2005 against trousers, shirts, underwear, cotton yarn, and synthetic filament fabrics from China. ${ }^{64}$ In addition, the coalition also filed three separate petitions, requesting that the United States extend safeguards on four trade and clothing categories from China that expired on December 23, 2004: knit fabrics, brassieres, dressing gowns, and robes. ${ }^{65}$

The United States Court of International Trade (CIT) granted preliminary injunctive relief on December 30, 2004 in response to a complaint filed by the United States Association of Importers of Textiles and Apparel. ${ }^{66}$ Plaintiff sought to enjoin defendant pending these legal proceedings, "from accepting, considering, or taking any further action on requests filed under the procedures issued by the Committee for the Implementation of Textile Agreements . . . that are based on the threat of market disruption upon the elimination of quotas or safeguards on textile or textile products from . . . China." ${ }^{67}$ In granting this temporary relief, the

\begin{abstract}
2. Implement automatic and seamless transitional safeguard mechanisms in order to prevent massive disruptive surges of trade from a few countries. The damage associated with the removal of a limited number of quotas in 2002 under the third stage of the phase-out must not be repeated. For example, during that removal, almost all the benefits went to a single supplier, which significantly cut prices.
\end{abstract}

3. Demand expedited and effective remedies to all types of unfair trading practices employed by certain major supplying countries, including currency manipulation, state sponsored subsidies and state provided non-performing loans, among others. Id.

63 Cf. Nordås, supra note 53, at 26. This simulation of the impact of phasing out ATC quotas, predicts, "Since the United States/Canada has the most restrictive quotas, the impact on import share of total demand is the most dramatic here. The import share in clothing will increase by as much as a third according to the model simulations." $I d$.

64 See Hong Kong Trade Development Council, Developments in the Textiles and Clothing Trade: Impact of Quota Elimination from 2005, http://www.tdctrade .com/econforum/tdc/tdc050103.htm.

65 Id.

66 See U.S. Ass'n of Imps. of Textiles and Apparel v. United States, 350 F. Supp. 2d 1342 (Ct. Int'l Trade 2004).

67 Id. at 1344. 
CIT considered several factors, including the immediate and irreparable injury to the plaintiff, the balance of hardships between the plaintiff and defendant, the likelihood of success on the merits by the plaintiff, and what would best serve the public interest. ${ }^{68}$

However, upon a showing of sufficient evidence of a market disruption caused by a surge in imports, the granting of preliminary injunctive relief will not stay safeguard quotas. ${ }^{69}$ China's accession to the WTO contains a temporary special protection clause (the Transitional Product-Specific Safeguard Clause in section 16 of the WTO Protocol on Accession) that may be invoked until 2008 by either the United States or the European Union if their home markets are threatened by excessive imports of textiles and clothing products. ${ }^{70}$ In addition, general safeguard

68 Id. at 1346.

69 Hong Kong Trade Development Council, supra note 64; See also Hong Kong Trade Development Council, Update on China Safeguard Litigation: CIT Denies Government Request for a Stay, Feb. 22, 2004, http://www.tdctrade.com/alert/ us0503c.htm.

The US government submitted a notice of intent to appeal to the US Court of Appeals for the Federal Circuit (CAFC) on 26 January, and one day later filed a motion with the CIT requesting a "stay" of the injunction pending conclusion of the appellate proceedings. The CIT denied the stay request four days after it was filed, leaving the injunction in place. The CIT also refused to respond to a request by the US Sock Manufacturers and Distributors Coalition to clarify the scope of the preliminary injunction. The initial suit covered the safeguard action on socks and the Coalition requested that the judge force CITA to lift the associated quota. The safeguard limit on socks therefore remains in place. The US government has filed an additional motion to stay the preliminary injunction with the CAFC, and is also requesting an expedited briefing schedule at that court for its appeal of the injunction. USA-ITA, the plaintiff in this case, has announced that it will "strongly oppose the stay motion" and advised the US government that it supported an expedited schedule, but not the schedule proposed by the Government. The US Government filed an appeal brief with the CAFC on 14 February 2005. Id.

70 See Eric Heymann, WTO Textile Agreement Now Expires: China MATURING INTO WORLD's TAILOR 26, (Hans-Joachim Frank ed. 2005), http://www. dbresearch.com/PROD/DBR_INTERNET_EN-PROD/PROD0000000000184480.pdf; see also WTO, Protocol on the ACCession of the PEOPLE's RePublic of China, 9, 11 (2001), http://docsonline.wto.org/DDFDocuments/t/WT/L/432.doc [hereinafter Protocol on ACCEsSion]; see also Terence P. SteWART, U.S.-China SECURITY AND ECON. Rev. COMm'n, China's COMPliance With World Trade Organization OBLIGATIONS 64 (2004), http://www.uscc.gov/researchpapers/2004/stewartpaper/ 04_03_19finalreport.pdf. The Transitional Review Mechanism or process is unique to China and is required by Article 18 of the Protocol on Accession, [hereinafter TRM]. 
provisions for many products, including textiles and clothing products, are possible until 2013. ${ }^{71}$

In Europe, the situation has been no less dramatic as the European Union also braces itself to respond to this potential global economic crisis. In February 2005, soon after a similar request by Portugal, Italy requested the European Commission (EC) place a limit on imports of textiles from mainland China. ${ }^{72}$ Italy claimed that Chinese products flooded the European Union markets following the termination of the ATC. ${ }^{73}$

In March 2005, the European Union Commission released provisional anti-dumping findings regarding certain finished polyester filament apparel fabrics (FPFAF), which are woven fabrics of synthetic filament yarn containing eighty-five percent or more by weight of textured or non-textured polyester filaments, dyed or printed, and normally used for apparel applications. ${ }^{74}$ FPFAF is used for making anoraks, sports wear, ski wear, underwear, lining for clothing, and other fashion items. ${ }^{75}$ The EC's findings resulted in the imposition of provisional duties on all exporting producers from China. ${ }^{76}$ AIUFASS, ${ }^{77}$ acting on

Id.; see also Joel P. Trachtman, United States-Restrictions on Imports of Cotton and Man-made Fibre Underwear, 9 EUR. J. INT'L L. 402 (1998), http://www.ejil.org /journal/Vol9/No2/sr3.rtf (analyzing the WTO Appellate Body report addressing causation and proof of serious damage and interpreting the ATC).

71 See HeYmanN, supra note 70; see also International Trade Center, Extract of Report of the Working Party on the Accession of China - Special Textile and Clothing Safeguards against China, http://www.intracen.org/textilesandclothing/accession_of_ china.htm.

72 Hong Kong Trade Development Council, Threat of Safeguards Against Chinese Textiles Looms Larger, May 2005, http://www.tdctrade.com/alert/eu0505.htm.

73 Id.

74 Hong Kong Trade Development Council, Provisional Findings Published in Textiles Anti-dumping Case, Mar. 31, 2005, http://www.tdctrade.com/alert/eu0506c.htm ("Findings published in the Official Journal of 16 March 2005 under Commission Regulation 426/2005.").

75 Id.

76 Id.

77 The International Association of Users of Artificial and Synthetic Filament Yarns and of Natural Silk is an affiliate of Euratex. Euratex is the European Apparel and Textile Organisation which "acts on behalf of the European textile and clothing industry with European institutions on matters of common interest, relating to decisions or legislation affecting the industry." Euratex.org, About Euratex, http://www.euratex.org/. 
behalf of several EC producers, initiated the proceeding on June $17,2004 .^{78}$ An investigation revealed that exporting producers were selling this product to the European Union at a price lower than on their domestic market. ${ }^{79}$ There were significant increases in volumes and market shares of imports from China, which significantly undercut the prices of the EC industry. ${ }^{80}$ The EC concluded such imports injured the EC industry and thus duties should be imposed. ${ }^{81}$ Most importantly, this proceeding and subsequent findings indicate how the European Union may deal with future anti-dumping cases involving textiles from China. ${ }^{82}$ On May 22, 2005, the European Union also indicated that it had no desire at that time to impose quotas on China, but needed to ensure appropriate management of future textile exports because a surge of cheap textile and clothing shipments may require quotas. $^{83}$

In an earlier response to concerns of trading partners and in anticipation of the termination of the ATC on January 1, 2005, China imposed tariffs on six categories of textile exports commencing on the same date. ${ }^{84}$ China announced that it would collect export tariffs, ranging from 0.2 yuan to 0.3 yuan (2.4-3.6 U.S. cents) for every piece or set on 148 types of clothing. ${ }^{85}$ On January 1, 2005, many countries removed textile-trading quotas as scheduled, including the United States, the European Union, and Canada. ${ }^{86}$ In addition, on May 20, 2005, China's Tariff Committee of the State Council decided, for the second time, to impose export duties on another 74 ten-digit tariff lines. ${ }^{87}$ China's

78 Hong Kong Trade Development Council, supra note 74.

79 Id.

$80 \mathrm{Id}$.

81 Id.

82 Id.

83 EU Not Desired to Reimpose Quotas on China's Textiles, CHINA DaILY, May 22, 2005, http://www2.chinadaily.com.cn/english/doc/2005-05/22/content_444633.htm.

84 See Dai Yan, Textile Export Curbs to Remain, ChINA DAILY, Jan. 5, 2005, http://www2.chinadaily.com.cn/english/doc/2005-10/05/content_406099.htm; see also Dai Yan, Textile Tariff Details Unveiled, CHINA DAILY, Dec. 28, 2004, http://www2.chinadaily.com.cn/english/doc/2004-12/28/content_403844.htm.

85 See also Textile Tariff Details Unveiled, supra note 84.

86 Dai, Textile Export Curbs to Remain, supra note 84.

87 Ministry of Commerce of the People's Republic of China, Commerce Minister 
MOFCOM imposed export tariffs to address concerns of trade partners. ${ }^{88}$ However, China's self-imposed voluntary export tariffs, or voluntary export restraints (VERs), on certain exportable commodities did not sufficiently belie global economy fears.

On May 14, 2005, the United States reimposed quotas, or more accurately, emergency curbs, on three categories of textiles and clothing imports from China. ${ }^{89}$ The import quotas both directly addressed Chinese textiles and clothing and benefited some developing countries such as India and Pakistan. ${ }^{90}$ In particular, the United States reimposed quota ceilings on cotton trousers (categories 347/348), cotton knit shirts (categories 338/339), and underwear (category 352) imported from China. A surge of Chinese imports and fear of jobs being lost in the United States prompted the reimposition of tariffs. ${ }^{91}$ According to United States Commerce Secretary Carlos Gutierrez, since quotas were eliminated on January 1, 2005, a surge in imports from China has severely harmed domestic industry. ${ }^{92}$ As of July 12, 2005, unless the United States and China sign a bilateral agreement increasing the quota limits for certain categories of clothing so that if such merchandise is shipped in excess of the applicable quota, it will not be allowed United States entry until February $1,2006 .{ }^{93}$ On July 5, 2005, according to the U.S. Customs and Border Protection

Bo Xilai Attending Press Conference Hosted by the State Council Information Office, ASIA REPORT, June 1, 2005, http://english.mofcom.gov.cn/aarticle/counselorsreport/ asiareport/200506/20050600106396.html.

88 ld. ("Some foreign companies have predicted Chinese Textile goods, supported by cheap labor costs, will flood the world market and force them out. Seventy-two textile and apparel groups from [thirty-six] countries have even made the 'Istanbul Declaration' to request the WTO extend quota-free deadlines until December 31, 2007, but it has failed.")

89 See Parvaiz Ishfaq Rana, US Slaps Quotas on China's Clothing, Dawn THE INTERNET EDITION, May 15, 2005, http://www.dawn.com/2005/05/15/ebr1.htm.

90 Id.

91 Id.

92 Id.

93 Hong Kong Trade Development Council, Four Safeguard Quotas Embargo in July; Textile Industry Files Additional Petitions, July 21, 2005, http://www.tdctrade.com/alert/us0514.htm. The agreement increased quota limits on categories of cotton knitted shirts and blouses (category 338/339), cotton and man-made fibre underwear (category 352/652), cotton trousers (category 347/348), and man-made fibre knitted shirts and blouses (category 638/639). Id. 
(CBP), import of these categories of textiles and clothing came to a halt as each of these limits had already been filled. ${ }^{94}$

In the meantime, on June 11, 2005, China and the European Union executed a Memorandum of Understanding (MU) on textiles and clothing. ${ }^{95}$ Under the terms of the MU and pursuant to voluntary export restraints, "the annual growth of textile exports to Europe for the ten lines of Chinese products is set to rise between eight and 12.5 percent from June 11, 2005 through 2007." "96 The agreement covers "ten lines of textile products," including "cotton cloth, t-shirts, pullovers, trousers, blouses, sheets, dresses, brassieres, table cloth and flax yarn."97 According to the MU, the European Union also agreed to stop investigations on ten categories of textile products from China. ${ }^{98}$ According to Zhang Hanlin, the director of the Research Institute on the WTO at China's University of International Business and Economics, "Pushed by the Sino-European Union agreement, the trade talks between China and the United States on textile exports are expected to make substantial progress in the near future." 99

During the 2005 annual meeting of the United States-China Joint Commission on Commerce and Trade (JCCT), the parties agreed that China would undertake specific actions in the areas of protecting intellectual property rights, increasing market access for U.S. goods and services, and accounting of subsidies, which is a

94 Id.

95 People's Republic of China Ministry of Commerce, Sino-EU Textile Agreement Sets Good Example for Future Trade Talks, AsIA REPORT, June 13, 2005, http://english.mofcom.gov.cn/aarticle/counselorsreport/asiareport/200506/200506001170 58.html; see also Xinhua, German Textile Organization Chief Hails China-EU Deal on Textile, PEOPLE's DAILY ONLINE, June 17, 2005, http://english.people.com.cn/200506/17/ eng20050617_190736.html.

96 Xinhua, German Textile Organization Chief Hails China-EU Deal on Textile, supra note 95.

97 Embassy of the People's Republic of China in India, EU Agrees to Stop Probe on Chinese Textile, REPORTS From CHINA, June 13, 2005, http://www.chinaembassy .org.in/eng/zgbd/t199635.htm.

98 Id.

99 People's Republic of China Ministry of Commerce, Sino-EU Textile Agreement Sets Good Example for Future Trade Talks, ASIA REPORT, June 13, 2005, http://english.mofcom.gov.cn/aarticle/counselorsreport/asiareport/200506/200506001170 58.html. 
Protocol on Accession yet to be fulfilled. ${ }^{100}$ The countries also jointly agreed to intensify discussions on structural issues related to China's non-market status under U.S. anti-dumping laws, including a review of China's subsidy practices. ${ }^{101}$ While the parties discussed a potential agreement to limit Chinese textiles and clothing exports, there were no specific breakthroughs. ${ }^{102}$ The failure to reach a concrete agreement was in part attributable to speculation that China might revalue its currency, which it did in July $2005 .^{103}$ The revaluation of the Chinese yuan, though slight (only a 2.1 percent change in the yuan from its fixed value of 8.3 to the U.S. dollar), may have brought about concessions from both Washington and Beijing. ${ }^{104}$ For China, the revaluation may have produced a trading partner more willing to reduce Chinese textiles and clothing quota limits met on July 5, 2005. The United States, although doubtful that the revalued yuan will reduce the U.S.China trade deficit, which topped at $\$ 162$ billion in 2004, hopes to placate domestic constituents and lobbyists, such as the U.S. Trade and Clothing Industry Coalition and labor unions. ${ }^{105}$

100 U.S. Dept. of State, United States Issues Fact Sheet on JCCT Trade Talks with China (Jul. 11, 2005), http://usinfo.state.gov/eap/Archive/2005/Jul/12-405893.html; see also Press Release, Office of the U.S. Trade Representative, JCCT Press Conference with USTR Portman, Commerce Secretary Carlos M. Gutierrez and Agriculture Secretary Michael Johans (Jul. 11, 2005), http:/www.ustr.gov/Document_Library/ Transcripts/2005/July/JCCT_Press_Conference_with_USTR_Portman,_Commerce_Secr etary_Carlos_M._Gutierrez_Agriculture_Secretary_Michael_Johanns.html.

101 U.S. Dept. of State, supra note 100.

102 Hong Kong Trade Development Council, U.S.-China Achieve Concrete Results at JCCT Talks, July 21, 2005, http://www.tdctrade.com/alert/us0514.htm.

103 Andy Mukherjee, China Has Revalued Yuan; What Happens Next?, Bloomberg.com, July 22, 2005, http:/quote.bloomberg.com/apps/news?pid= $10000039 \&$ refer=columnist_mukherjee\&sid=ayvzBLIp6Ipk.

104 Morris Goldstein \& Nicholas R. Lardy, Op-Ed., China's Revaluation Shows Size Really Matters, Fin. TIMES, Jul. 22, 2005, http://www.iie.com/publications/ opeds/oped.cfm?ResearchID $=528$.

105 Bruce Odessey, Swiftly Expanding U.S.-China Economic Relations Stir Debate, Mar. 2, 2005, U.S. Department of State, International Information Program, http://usinfo.state.gov/eap/Archive/2005/Mar/03-588739.html; see, e.g., M. Ulric Killion, China's Foreign Currency Regime: The Kagan Thesis and Legalification of the WTO Agreement, 14 MiNN. J. Global TRADE 43, 49-53, 61-65 (2004) (discussing the China yuan controversy, U.S.-China trade policy and domestic constituents, and lobbyists). 


\section{The Political Economy of China}

The 2004 ASEAN-China Accord, in conjunction with termination of the ATC, presents issues of China-led regionalism. More specifically, the accord and termination raise the question of whether there is a distinctive model of Chinese regionalism that threatens multilateral world trade. China's approach to regional integration may be unilateral or multilateral. Generally, regional trade agreements are analyzed in terms of the conventional or orthodox model of market-led cooperative regionalism, ${ }^{106}$ a model of regionalism that complements, rather than threatens, multilateral trade and the goals of the WTO. Notwithstanding issues such as economic regionalization versus economic regionalism, ${ }^{107}$ or microregionalization versus microregionalism, ${ }^{108}$ economic globalization has presented the paradoxical inter-relationship between what is more accurately described as market-led regionalization and policy-led regionalism. $^{109}$ Consequently, economic globalization produced a paradoxical conflict between market transactions (market actors in bottom to top process) and state policies (state actors in top to bottom process) seeking to manage an integrating social space

106 See, e.g., Warwick J. McKibbin \& Wing Thye Woo, The Consequences of China's WTO Accession on its Neighbours (Oct. 18, 2002) (on file with the University of Michigan), http://www.wdi.bus.umich.edu/CEDS papers/Woo_Wing_Thye.pdf; Linda Low, East Asian Regionalism: Would that Help Globalisation, Growth and (In)Equality?, Paper for Globalisation, Growth and (In) Equality, 5th Centre for the Study of Globalisation and Regionalisation Annual Conference, coorganized by University of Warwick, CSGR and Economic \&V Social Research Council, University of Warwick (March 15-17, 2002), http://ww.warwick.ac.uk/fac/soc/GSGR/PLow.pdf, citing John G. Ikenberry, The Political Economy of Asian Regionalism, 11 ASIAN ECON. PERSPECTIVES 35 (2000).

107 See Mark Beeson, Re-thinking Regionalism: Europe and East Asia in Comparative Historical Perspective, at 3, Paper presented at the Oceanic Conference on International Studies, Canberra (July 14-16, 2004).

Consequently, much recent scholarship about regional processes makes a basic distinction between regionalism and regionalization. In this formulation, regionalism refers to the political process in which states drive cooperative initiatives. Regionalization, by contrast, refers to processes of economic integration which, while they may be influenced by state policies, are essentially the uncoordinated consequence of private sector activities. Id.

108 See, e.g., Shaun Breslin, Decentralisation, Globalisation and China's partial Reengagement with the Global Economy, 5 NEW POL. ECON. 207 (2000).

109 Id. 
across sub-national, interregional, and international borders. ${ }^{110}$ As the role of state actors and their attendant policies and practices become increasingly relevant in measuring regional integration, political economy environments arguably serve as indicators of the directional development of this paradoxical conflict, especially when seeking to measure the international trade practice and policies of socialist-political polities such as China. For instance, notwithstanding political motivations, in China the political economy forces driving economic integration have been resource endowments and differing developmental levels (foreign capital and technology, and domestic land and labor) in pursuit of exportbased growth. ${ }^{111}$ However, China's most important problems are its political economy environment and inclusive political motivations, which arguably produce unconventional and unorthodox approaches to economic growth, economic development, and especially regional integration. The latter is problematic because it suggests that China's polity may be pursuing an international trade policy focusing on unilateral liberalization, rather than multilateral liberalization. All of this might pose a threat to the multilateral world trading system.

In terms of the globalization of China, many commentators advocate a "big bang" approach to transition from socialism to capitalism in legal reform and economic development. ${ }^{112}$ Many argue that speed is of the essence, because there was a "window of opportunity" (or a honeymoon period or a period of exceptional politics) created by the establishment of a democracy. ${ }^{113}$ During this period, some scholars contend, "governments should adopt reforms as fast as possible and attempt to make them irreversible."114 Despite the many proponents of a "big bang" approach, China has been relatively successful in its "gradualist" approach to transition.

$110 \mathrm{Id}$.

111 See Robert F. Ash \& Y.Y. Kueh, Economic Integration within Greater China: Trade and Investment Flows Between China, Hong Kong and Taiwan, in GREATER CHINA: THE NEXT SuPERPOWER? 60 (David Shambaugh, ed., 1995).

112 See Gerard Roland, The Political Economy of Transition 37-38 (William Davidson Institute, Working Paper No. 413, 2002), http://wdi.umich.edu/files/ Publications/WorkingPapers/wp413.pdf.

113 Id.

114 Id. 
To the disdain of Western models of development, China's ongoing transition to a market economy has occurred without democratization, liberalization has been slow and incremental, and privatization has been delayed. ${ }^{115}$ In the past two decades, the Western world witnessed remarkable success in its reforms. China, India, and other Asian countries liberalized trade and investment, but did so in an unorthodox manner; that is, gradually, sequentially, and only after an initial period of high growth, all of which occurred within the confines of broader policy packages with unconventional features. ${ }^{116}$ Nonetheless, China, if not China's polity, is struggling for survival in terms of domestic, regional, and international relations. On the domestic front, China faces problems directly relating to such issues, which present overriding political economy concerns that affect Chinese policy in politics, economics, and trade.

China's distinctiveness lies in the fact that accession followed the 1991 breakup of the Soviet Union and Council for Mutual Economic Assistance (COMECON or CMEA), which was the economic and trading system of East European countries connected to the Soviet Union. ${ }^{117}$ The breakup of the Soviet Union created the possibility of additional transition economies seeking General Agreement on Tariffs and Trade (GATT) membership. ${ }^{118}$ Since the rules of accession for China may serve as a model for additional transitional economies, Western developed countries implicitly created special conditions and rigorous accession terms for China. ${ }^{119}$ For this reason, China presents a classic example of ongoing legal and economic reform,

115 See Dani Rodrik, Globalization Is No Shortcut to Development, BEYOND Transition (World Bank Group, Washington, D.C.), July-Sept. 2001.

116 Id.

117 See, e.g., Czechoslovakia: A Country Study 273 (Glenn E. Curtis ed., Federal Research Division of the Library of Congress 1992), http://www.shsu.edu/ his_ncp/CMEA.html ("The Founding of the Council for Mutual Economic Assistance (also referred to as Comecon, CMEA, CEMA, or the Council) dates from a 1949 communiqué agreed upon by the Soviet Union, Bulgaria, Czechoslovakia, Hungary, Poland, and Romania.").

118 See Nicholas R. LARdy, Integrating China into the Global Economy 6163 (Brookings Institute 2002); see also PROTOCOL ON ACCESSION, supra note 70; TRM, supra note 70 .

119 LARDY, supra note 118. 
or institutional reform, prompted, at least in part, by both the WTO Protocol on Accession and Trade Review Mechanism (TRM). In terms of Western development taxonomies, China remains a nonmarket economy transitioning to a market economy under standards imposed by both the WTO Protocol on Accession and the TRM. ${ }^{120}$

China's accession to the WTO in 2001 was not the end of the transformation of its trading system and accession obligations. WTO members determined that China needed to accomplish substantial changes before it would be in full compliance with the accession obligations. $^{121}$ For this reason, an annual monitoring mechanism was created that focused on China's compliance with the obligations of WTO membership. ${ }^{122}$ In the Protocol on Accession, China agreed to an annual review of the implementation process, known as the TRM. ${ }^{123}$ Commenced in 2002, the TRM will operate for eight consecutive years, followed by one final review of China's compliance and implementation process in the tenth year subsequent to accession. ${ }^{124}$ For China, compliance entails, at a minimum, a commitment to the WTO goal of multilateral trade, if not to a model of regionalism that complements multilateral trade.

China continues to experience rapid economic growth and is hailed by many as exemplary in its open door policy. ${ }^{125}$ However, economic liberalization in China is best described as "relative" economic liberalization. ${ }^{126}$ Pursuant to the Protocol on Accession

120 Id.

121 Id.

122 See Monitoring and Enforcement of the People's Republic of China's WTO Commitments, 22 U.S.C. $\S 6931$ (2000). The United States, for example, explicitly made an annual review of China's compliance with its WTO obligations an element of its national trade policy. In the bill that extended nondiscriminatory treatment (normal trade relations treatment) to the People's Republic of China, Congress expressly provided, "It shall be the objective of the United States to obtain as part of the Protocol of Accession of the People's Republic of China to the WTO, an annual review within the WTO of the compliance by the People's Republic of China with its terms of accession to the WTO." Id.

123 See PROTOCOL ON ACCESSION, supra note 70.

124 Protocol on ACCESSION, supra note 70; TRM, supra note 70.

125 See Sebastian Mallaby, China: A Better Economic Global Citizen Than Guessed, WASH. POST, June 7, 2005.

126 For purposes of this article, China's relative liberalization reflects the degree of 
and the TRM, liberalization occurs in all sectors of an economy. China's relative liberalization is evidenced by several factors, ${ }^{127}$ such as a growing disparity in income between the rich and poor, ${ }^{128}$ a disparity in economic development between coastal regions and western provinces, ${ }^{129}$ and remnants of Soviet style planning, a command system. ${ }^{130}$ As one source observed, "China

China's integration into the global economy, in terms of deep integration versus swallow integration. See U.S.-China Security Review Comm. Technical Briefing on Business, Trade, and Economic Issues: Hearing Before the U.S.-China Security Review Comm., 107th Cong. 1425 (2002) (statement of Nicholas R. Landy) ("Despite this extraordinary performance, China remained in certain respects only shallowly integrated into the world economy.").

127 See id. (explaining that critical sectors of the Chinese economy remains relatively insulated from international competition); see also Mari Pangestu \& Debbie Mrongowius, Telecommunications Services in China: Facing the Challenges of WTO Accession, in CHINA AND THE WTO: Accession, POlicy REFoRM, AND POVERTY REDUCTION STRATEGIES 157 (Deepak Bhattasali, William J. Martin, and Li Shantong, eds., 2004) ("China's telecommunications sector since the country's accession to the World Trade Organization (WTO) remains one of the most restricted and regulated of those in the major developing countries in the region.").

128 See, e.g., Guanghua WaN \& Zhangyue Zhou, Income InEquality IN RURAL China Regression Based Distribution USING Household Data 2 (2004), http://www.wider.unu.edu/publications/rps/rps2004/rps2004/rp2004-051.pdf\#search ='income\%20inequality\%20in\%20rural\%20china\%3A\%20regressionbased'; see also Pangestu \& Mrongowius, supra note 127.

129 See also Huitong WANG, InTEgrated Study of China's Development AND Reform Preliminary ExPloration of Social System 105-106 (Beijing, Foreign Language Press 2003) (discussing China's regional development strategies and problems) ("China is now at the primary stage of socialism. It is pointed out by President Jiang Zemin that 'It is a stage in which a society with very uneven economic and cultural development among regions will become one in which the gap will be gradually narrowed ...."”).

130 See Toshiki Kanamori \& Zhijun Zhao, Private Sector Development in the People's Republic of China, ASIAN DEv. BANK INST. (Oct. 2004) http://www.adbi.org/book/2004/10/07/602.private.sector.prc/ ("The market economy is an opposing concept to the command or planned economy in the PRC."); see also Peter Batey, Capitalism and Compromise, CHINA Rev. MAG. Spring 2003, http://www.gbcc.org.uk/crmag.htm ("China is still far from being a market economy, though it has moved some way from the old Stalinist command economy system. The role of the Party and government in business remains all pervading, and even if the mechanisms for detailed intervention in economic management are gradually being dismantled, there is little doubt that a residual power to intervene at will remains."); Prabhat Patnaik, China in a Globalized World, FrontLine, Oct. 9-22, 1999, http://www.frontlineonnet.com/f1 1621/16210120.htm.

Thirdly, to call China a neo-liberal "model" is a travesty. China's success during the reform years has sprung precisely from the fact that it has managed 
is still far from being a market economy, though it has moved some way from the old Stalinist command economy system.",131

The 2004 report of the United States-China Economic and Security Commission noted some progress by China in meeting its WTO accession commitments, but concluded that China "still maintains non-tariff barriers and is erecting new non-tariff barriers that harm United States interests by effectively limiting market access for United States goods and services."132 The report charged China with frustrating the effectiveness of the TRM, thus preventing the TRM from becoming an effective mechanism for assessing compliance and for placing multilateral pressure on China to address shortfalls. ${ }^{133}$ As the United States-China Economic and Security Review Commission stated in its 2004 annual report to Congress, "[United States] business groups that lobbied hard in favor of granting Permanent Normal Trade Relations (PNTR) status to China in 1999-2000, and applauded China's entry into the WTO, are now expressing concerns over the pace and scope of WTO compliance."134 The representative groups are the United States-China Business Council, American Chamber of Commerce in China, United States Chamber of

to combine in an altogether novel way the virtues of centralisation with those of decentralisation, or, putting it differently, the advantages of a command economy alongside the flexibility imparted by the functioning of markets. It has been, if you like, a command economy at one remove.

131 Batey, supra note 130.

132 U.S.-CHINA ECONOMIC AND SECURITY REVIEW COMMISSION, 108Th CoNG., 2004 REPORT TO CONGRESS 61 (Comm. Print 2004), http://www.uscc.gov/researchpapers/ 2004/04annual_report.pdf [hereinafter REVIEW COMMISSION REPORT]; see also U.S. TRADE REPRESENTATIVE, 2004 REPORT TO CONGRESS ON CHINA'S WTO COMPLIANCE 1 (2004), http://www.ustr.gov/assets/Document_Library/Reports_Publications/2004/asset_ upload_file281_6986.pdf.

This report is the third report prepared pursuant to section 421 of the U.S.-China Relations Act of 2000 (P.L. 106-286), 22 U.S.C. $\$ 6951$ (the Act), which requires the United States Trade Representative (USTR) to report annually to Congress on compliance by the People's Republic of China (China) with commitments made in connection with its accession to the World Trade Organization (WTO), including both multilateral commitments and any bilateral commitments made to the United States. The report also incorporates the findings of the Overseas Compliance Program, as required by section 413(b)(2) of the Act, 22 U.S.C. $\$$ 6943(b)(2).

133 See PROTOCOL ON ACCESSION, supra note 70.

134 REVIEW COMMISSION REPORT, supra note 132, at 67. 
Commerce, and National Association of Manufacturers. ${ }^{135}$

China's newly erected barriers to trade, which, when taken in conjunction with unaddressed compliance issues, create another problem because they challenge China's commitment to the multilateral world trading system. According to the U.S.-China Economic and Security Commission, the shortcomings of China's accession commitments are:

Continued direct and indirect subsidies to Chinese producers, including preferred and sometimes unserviced loans from stateowned banks, and free or discounted utility services; rampant abuse and lax enforcement of intellectual property rights; poor transparency in adopting and applying regulations; the use of unjustified safety standards to exclude foreign products-including non-science-based sanitary and phytosanitary (SPS) standards on agricultural products and the China Compulsory Certification of safety; the use of unjustified technical standards to exclude foreign products or force foreign producers into joint ventures with Chinese firms for production aimed at the Chinese market; denial of equal tax treatment to foreign products; barriers to specific services, such as financial services and express couriers; obstacles to domestic distribution of products by foreign companies, which severely curtails the ability of foreign companies to gain market share and forces them to sacrifice control over portions of the profit margin; and forced transfers of technology. ${ }^{136}$

The unaddressed compliance issues bring into question China's commitment to trade and investment liberalization and the goals of the WTO, especially a commitment to a model of regionalism that complements, rather than threatens, multilateral trade.

As previously mentioned, China's non-orthodox "gradualist" approach to economic development has been relatively successful. However, despite evolving into a major world player in gross trade volume, China presents an anomaly in terms of international politics and trade relations. External forces that China perceives as threats to internal security, including global terrorism, geopolitical changes in world politics, pro-democracy movements,

135 Id.

136 Id. at 65. 
the war in Iraq, and North Korea nuclear talks, present problems for neo-liberalism and its prescription of democracy for Chinese society. ${ }^{137}$ These perceived threats, whether real or not, influence ongoing legal reform and economic development.

At first sight, the economic data is impressive. Since initiating reform and an open-door policy some twenty-five years ago, the Chinese economy has experienced high rates of growth. Economic barometers show an average annual growth rate of 9.5 percent from 1978 to 1995 , and double-digit rates for four consecutive years, from 1992 to $1995 .{ }^{138}$ In 2003, projections from China indicated that China's economy would grow at the rate of eight percent in 2004 and FDI would continue to grow rapidly. ${ }^{139}$ In 2003, China's foreign trade ministry predicted China's GDP for 2004 would be seven percent higher than in 2003. ${ }^{140}$ In 2005, China's annual economic growth prediction in terms of GDP is nine percent. ${ }^{141}$

Despite economic data presenting a case for ongoing successful globalization in terms of global trade, there remain tremendous legal, socioeconomic, and political issues confronting China. When one juxtaposes the economic data with the plight of the Chinese people and many problems confronting domestic China, the picture grows dimmer. In select areas of China, such as Shanghai and other coastal cities, one witnesses a seemingly surreal growth of materialism and consumerism. While rural Chinese, especially farmers, struggle for mere subsistence, 46.8 percent of the Chinese population live under a media-fabricated myth that they are part of a growing middle class. ${ }^{142}$ In 2003, the

137 See Jianwei Wang, Tough Road Ahead for China's Foreign Minister, ASIA Times ONLINE, Apr. 2, 2003, http://www.atimes.com/atimes/China/ED02Ad01.html.

138 See John Wong, China's Post-Deng Xiaoping Economy: Problems and Prospects, (Int'1 Univ. of Japan Research Inst., Working Paper No.1, 1997), http://www.iuj.ac.jp/research/wpap001.cfm.

139 Id.

140 See Fu Jing, Rosy Forecast of Economic Growth, ChINA DaILY, Nov. 6, 2003; see also Lena Lee, Foreign Investors, Retail Sales Set the Pace in China, ASIAN WALL ST. J., Mar. 26, 2004, at A2; see also China set 7\% growth target for 2004, News Guangdong (via China Daily), Dec. 3, 2003, http://www.newsgd.com/business/ prospective/200312030031.htm.

141 See Developments in Selected Non-member Economies, at 2 (preliminary edition, OEDC Economic Outlook No. 77, 2004), www.oecd.org/dataoecd/36/11/20213290.pdf.

142 See Pepe Escobar, The Great Wall of Shopping, Asian Times OnLINE, Jan. 14, 
average per capita disposable income in urban areas was 8472 yuan (\$1033) a year, while for farmers it was only 2622 yuan (\$319) a year. ${ }^{143}$ China's agricultural economy now employs about fifty percent of the labor force. ${ }^{144}$ They are members of China's lowest average income group, which constitutes about 630 million persons or half of China's population, comprising mostly the poverty-stricken, ethic minority, rural areas and remote areas, in the central and western regions.

Although a consensus has been reached concerning the increasing trend in income inequality in China, the same does not hold true regarding the causes of this trend. ${ }^{146}$ China's population peaked in January 2005 at 1.3 billion; the country expects corresponding peaks in elderly populations and migrant populations (rural to urban) as well as a growing imbalance in gender proportions. ${ }^{147}$ In the face of a burgeoning population, China's domestic policy of the 4-2-1 phenomenon (si-er-yi jiating jiegou), or having four grandparents and two parents to support will continue to put China's only children under great financial strain. ${ }^{148}$ Notwithstanding an abatement of this growth trend in population, which has been a worsening trend since the 1970s, the predicted result is growing income disparities that will adversely

2005, http://atimes.com/atimes/China/GA14Ad04.html.

143 Id.

144 Angang $\mathrm{Hu} \&$ Yizhi Xiong, The Strategy of Knowledge-based Development: China's Long-run Future, Soc. SCI. IN CHINA (Zhongguo shehui kexue), Winter 2003, at $24-25$.

145 Id.

146 Guanghua \& Zhangyue, supra note 128 , at 1 ; see also Pangestu \& Mrongowius, supra note 127.

147 See China's Population Hits 1.3 Billion, Wash. Times, Jan. 3, 2005, http://www.washtimes.com/upi-breaking/20050103-091210-4944r.htm.

148 Fu Jing, More Capital to Tackle Pension Deficit, CHINA DaILy, Mar. 28, 2005.

China's Ministry of Labor and Social Security has forecasted that the number of retired persons living in urban areas will increase to 70 million in 2010 , and then to 100 million by 2020 . In urban areas, there are currently 48 million persons of pension age, but only 44.9 percent of urban employees and 85.4 percent of retired persons are covered by pension plans, while most farmers are outside the pension system. While it has been suggested that the retirement age be increased from now 55 for women and 60 for men to 65 for everyone, such a solution will only exacerbate the current job situation of 10 million unemployed persons. Id. 
affect China's ability to maintain sustainable growth and will eventually contribute to undermining social and political stability. ${ }^{149}$

The latter problems are a symptom of the proclivity of China's polity to employ ideological remedies in response to domestic, regional, and international problems. One such example is former President Jiang Zemin's doctrine of "The Theory of the Three Represents" (San Ge Daibiao), which was constitutionalized in an amendment to the 1982 China Constitution on March 14, 2004. ${ }^{150}$ The 2004 constitutional amendments incorporated the "Three Represents" into "the Constitution's preamble as one of the guiding principles of the nation, together with the heritage and further development of Marxism, Leninism, Mao Zedong Thought and Deng Xiaoping Theory." 151 The "Three Represents" said the Chinese Communist Party (CCP) means "the party must represent China's advanced productive forces, an orientation towards advanced culture, and the fundamental interests of the overwhelming majority of the people in China."152 The "Three Represents" is generally perceived as either widening party ranks by inclusion of capitalists and entrepreneurs, or conversely, creating deeper divisions between the rich and poor. ${ }^{153}$ However, most importantly, the "Three Represents" indicates the problems inherent in the Chinese economy, especially survivability of a socialist polity in a world market economy.

China's problems are many and varied, especially since it is jointly pursuing a socialist-political polity and capitalist-economic policy. The latter incongruence will never resolve to an effective

149 See GuANGHUA \& ZHANGYUE, supra note 128.

150 See Jiang's Book on Party Building Published, PeOPle's DaILy OnLINE, Nov. 11, 2001, http://english.peopledaily.com.cn/200111/08/eng20011108_84158.shtml. “On Party Building" (Lun Dang De Jianshe) is a 300,000 Chinese character book containing fifty-four speeches of Jiang Zemin, General Secretary of the CPC from December 1989 until September 2001. Id.

151 Human Rights, Private Property Fixed as Pillars, ChInA DAILY, Dec. 23, 2003, http://www.chinadaily.com.cn/en/doc/2003-12/23/content_292557.htm.

152 Id.

153 Barbara Foley, From Situational Dialectics to Pseudo-Dialectics: Mao, Jiang, and Capitalist Transition, CulTuRAL LOGIC, 2002, http://eserver.org/clogic/ 2002/foley.html; see also Joseph Kahn, China Moves to Protect Property, but the Fine Print Has a Caveat, N.Y. TIMES, Dec. 22, 2003, at A1. 
domestic, regional, and international development policy because of a political economy shrouded in the ideology of a governing party, the CCP. Governing polities such as the CCP will often compete by placing party survival and ideology, such as the "Three Represents," above other concerns, both domestic and global. In terms of the survival of China's CCP, the problems with reforms and the resulting problems in Marx-Leninist institutions necessitates the development of new and different state capacities. $^{154}$ However, continuing economic growth and improvement in living standards, in conjunction with the ideology of the "Three Represents," may provide China's polity with some degree of latitude in restructuring more stable institutions. ${ }^{155}$

Notwithstanding problems of a socialist-political government pursuing a capitalist-economic policy, another potential problem for China, as noted by a recent Organisation for Economic Cooperation and Development (OECD) study, is that the forces driving China's growth are losing their dynamism. ${ }^{156}$ Continuing economic growth in China may boil down to how China manages its macro economy, especially its monetary policy. Also of concern is how China deals with the liabilities of a developing and struggling banking sector and pension system. ${ }^{157}$ However, as one critic noted, "So long as the market is contaminated by party politics and state planning, corruption will continue to pollute China's economic environment."158

Domestic and international concerns in the political economy environment of China will affect Chinese international trade

154 See Barrett L. McCormick, Political Change in China and Vietnam: Coping with Consequences of Economic Reform, in TRANSFORMING ASIAN SOCIALISM 153, 161-162 (Anita Chan et. al. eds., 1999) (providing a defense of socialist democracy).

$155 \mathrm{Id}$.

156 See OECD, China in the World Economy, The Domestic Policy Challenges, at 910 (2002); see also AME Info.com, The China growth story to 2020, Jan. 14, 2005, http://www.ameinfo.com/news/Detailed/52154.html ("China's growth story seems never-ending. However, average growth of $9 \%$ each year over the last twenty-five years cannot last forever. China's economy will mature, and its fast rates of growth will calm.").

157 See, e.g., Yin-Wong Cheung, Menzi Chinn \& Eiji Fuji, The Chinese Economies in Global Context: The Integration Process and its Determinants (2003), http://repositories.cdlib.org/cgi/viewcontent.cgi?article=1013\&context+sccie.

158 See James A. Dorn, China's Spontaneous Order, ThE FrEEMAN: IDEAS ON LIBERTY, Apr. 1999, at 24-25. 
policy, especially China's approach to regionalism. China's polity exhibits a proclivity to employ ideological solutions in answer to societal problems. Given such proclivity, China's leaders may increasingly interject ideological and even political concerns into developing a distinctive Chinese model of regionalism. For example, China's decision to use FTAs was motivated by ideology and a desire to ensure ASEAN was China's first FTA partner. Chinese regionalism, primarily motivated by political considerations, presents an issue of whether Chinese regionalism threatens or complements multilateral trade.

\section{The WTO Rules}

Generally, FTAs are governed by Article XXIV of GATT $1947,{ }^{159}$ and the various trade agreements are generally described as follows:

Preferential Trade Agreements (PTAs) are agreements among a set of countries involving preferential treatment of bilateral trade between any two parties to the agreement relative to their trade with the rest of the world. Preferences, however, need not extend to all trade between the two, and the coverage could depend on the type of PTAs. Customs unions and the so-called free trade areas are common forms of PTAs. Members of most PTAs belong to a well-defined geographical area, such as for example, the European Union (EU), North American Free Trade Area (NAFTA) and Association of Southeast Asian Nations (ASEAN). For this reason regional PTAs are called Regional Trade Agreements (RTAs). The most common form of RTAs are the euphemistically named Free Trade Areas (FTAs), with few Customs Unions (CUs) which require the partners to maintain a common external trade policy, in addition to free trade with each other. ${ }^{160}$

An elemental principle embodied in the most-favored-nation (MFN) clause is that trade must be conducted on a nondiscriminatory basis. ${ }^{161}$ WTO members are bound to grant

159 See Free Trade Area Provision, supra note 20.

160 Srinivasan, supra note 17 , at 1.

161 GATT, Oct. 30, 1947, 61 Stat. A-11, T.I.A.S. 1700, 55 U.N.T.S. 194; see also GATT, art. I (outlining most favored-nation treatment); JOHN H. JACKSON, THE JURISPRUDENCE OF GATT \& WTO: INSIGHTS ON TREATY LAW AND ECONOMIC RELATIONS 101-02 (2002). 
treatment as favorable as they give to any country to each other in both the application and administration of import-export duties and charges. ${ }^{162}$ The underlying philosophy of multilateral trade is the idea that a combination of open markets, non-discrimination, and global competition create conditions that are most conducive to the national welfare of all nations. ${ }^{163}$

Exceptions to the aforementioned conditions are permitted only when special circumstances exist, such as CUs, RTAs, or FTAs, and when developing countries and economies need special assistance. ${ }^{164}$ Article XXIV of GATT 1947 allows WTO members to form CUs and FTAs. ${ }^{165}$ Paragraph five reads, "The provisions of this Agreement shall not prevent, as between the territories of contracting parties, the formation of a customs union or of a free trade area or the adoption of an interim agreement necessary for the formation of a customs union or of a free trade area." 166 Article XXIV permits such groupings as an exception to the general rule of MFN treatment. ${ }^{167}$ The purpose of Article XXIV is to ensure that regional integration complements and does not threaten the multilateral trading system. ${ }^{168}$

Generally, the MFN clause in Article I of GATT and the WTO prohibit countries from engaging in discriminatory practices against one another. ${ }^{169}$ However, FTAs and CUs are permissible under Article XXIV so long as they eliminate, rather than just lower, within-union trade barriers on "substantially all the trade." 170 In addition, the duties and regulations that affect the trade of members or aligned economies, such as FTAs or CUs, with nonmembers or nonaligned economies are also required to be no more restrictive than those that were in effect before such

162 See JACKSON, supra note 161.

163 See Moana Bhagabati, Regionalism vs. Multilateralism Debate, HINDU Bus. LINE, Mar. 28, 2001, http://blonnet.com/2001/03/28/stories/042820mo.htm.

164 GATT, pt. IV, arts. XXXVI-XXXVII, XXVIII.

165 Free Trade Area Provision, supra note 20.

166 Id.

167 JACKSON, supra note 161, at 101-102.

168 Id.

169 GATT, supra note 161.

170 Free Trade Area Provision, supra note 20, paras. 5, 8(a), 8(b). 
groupings were set up. ${ }^{171}$ Finally, those countries that enact FTAs and CUs are required to give notice to the WTO Council. ${ }^{172}$

Contrary to trade and investment liberalization, as well as the goals of the WTO, Article XXIV may implicitly permit, if not legalize, trade diversion by FTAs. Ironically, an important feature of multilateralism is the supposed absence of discrimination among trading partners because multilateral trade engenders trade and investment creation, and is welfare enhancing. ${ }^{173}$ An assumed characteristic of international trade agreements, such as NAFTA and the European Union, is that by virtue of their nature as international agreements, they frustrate protectionism. ${ }^{174}$ Whether these international agreements are actually welfare enhancing rather than welfare reducing is another issue because this conclusion does not necessarily apply to liberalization by a selective group of nations. ${ }^{175}$

Article XXIV has been referred to as the GATT loophole for FTAs. ${ }^{176}$ This clause, in effect, exempts FTAs and CUs from the obligation set forth in Article I to accord MFN treatment. ${ }^{177}$ This loophole is justified for two historical reasons. First, during the earlier post-World War II period, GATT was relatively successful as trade barriers were substantially lowered, and the number of contracting parties to GATT rose from twenty-three to more than $100 .^{178}$ For purposes of encouraging membership in the newly

171 Id. at para. 5 (requiring trade barriers after integration do not rise on average).

172 Id.

173 See OECD, The European Union's Trade Policies and their Economic EFFECTS 80 (2000).

174 See Stefan Szepesi, Coercion or Engagement?, Economics and Institutions in ACP-EU Trade Negotiations 8 (Eur. Center for Dev. Pol'y Mgmt., Discussion Paper No. 56, June 2004), http://www.ecdpm.org/Web_ECDPM/Web/Content/Content.nsf/0/ 1098B04D025BE761C1256EAD0039100E.

175 Id.

176 Srinivasan, supra note 17 , at 2.

177 GATT, art. I (outlining most favored-nation treatment).

178 Volker Nitsch \& Daniel M. Sturm, The Trade Liberalization Effects of Regional Trade Agreements, 2005, at 2, http://userpage.fu-berlin.de/ vnitsch/publications/05-0125.pdf.

The process of nondiscriminatory tariff reductions based on the General Agreement on Tariffs and Trade (GATT) was widely considered a success story. Trade barriers were lowered dramatically, with the average ad valorem tariff falling from over 40 percent to less than 4 percent . . ; the number of 
formed GATT (1947), the political reality of the post-World War II era meant accommodating a long history of CUs that predated GATT (1947). ${ }^{179}$ Second, exceptions were permitted under specific or controlled conditions, intending to avoid ad hoc and partial discrimination practiced during the interwar period. ${ }^{180}$

However, the primary political force leading to the creation of this loophole was the earlier formation of the European Economic Community (EEC). In the late 1950s, contracting parties made a conscious decision not to challenge the formation of the EEC so that it would not withdraw from GATT. ${ }^{181}$ During this period, EEC member states made it known that any discernable inconsistency between the Treaty of Rome and Article XXIV would have resulted in their withdrawal from GATT. ${ }^{182}$ This earlier crisis created an unwanted precedent that was, and continues to be, followed and at the same time produces an increasing tolerance for regional integration agreements. ${ }^{183}$

The WTO Memorandum of Understanding on Article XXIV also fails to clear up existing ambiguities and contradictions, ${ }^{184}$ such as differences regarding how to define "substantially all the trade," how to determine whether an external trade policy of an FTA has become more restrictive on "average," and what is a reasonable length of time for a transition to the full implementation of an FTA. ${ }^{185}$ As a result, Article XXIV remains a

contracting parties to GATT rose from 23 to more than 100; and growth in world trade consistently out-paced the expansion in merchandise output. Id. (citing Kyle Bagwell \& Robert W. Staiger, An Economic Theory of GATT, 89 AM. ECON. REv. 215 (Mar. 1999)).

179 Srinivasan, supra note 17 , at 2.

$180 I d$. at 2-3.

181 Bernard M. Hoekman \& Michel M. Kostecki, The Political Economy of THE World Trading SySTEM 353 (2d ed. 2001) (citing R. Snape, History and Economics of GATT's Article XXIV, in REgIONAL INTEGRATION AND THE GLOBAL TRADING SYSTEM (K. Anderson \& R. Blackhurst eds., 2003)).

182 Id.

183 Id.

184 WTO.org, WTO: Understanding on the Interpretation of Article XXIV of the General Agreement on Tariffs and Trade (1994), http://www.wto.org/english/tratop_e/ region_e/regatt_e.htm.

185 HoEKMAN \& KosTECKI, supra note 181 , at 353-54. 
continuing source of debate concerning FTAs. ${ }^{186}$ The problem is exasperated by the fact that only one working party has ever determined that an FTA or RTA satisfied Article XXIV. ${ }^{187}$ Since 1957 when the Treaty of Rome established the EEC, "almost no examination of agreements notified under Article XXIV led to a unanimous conclusion or specific endorsement that all the legal GATT requirements had been met."188 A comment from the chairperson of the working party for the 1989 Canada-United States FTA reads, "[o]ver fifty previous working parties on individual custom unions or free trade areas have been unable to reach unanimous conclusions on the compatibility of these agreements with the GATT-on the other hand, no such agreement has been explicitly disapproved." that as late as the 1980 s, only four such working groups could agree that a regional integration agreement actually met the requirements of Article XXIV. ${ }^{190}$

In addition, no FTAs or RTAs have ever been found to be incompatible with GATT. ${ }^{191}$ A GATT Study Group concerning Article XXIV reads, "[t]hey have set a dangerous precedent for further special deals, fragmentation of the trading system, and damage to the trade interests of non-participants . . . GATT rules on customs unions and free trade areas should be examined, redefined so as to avoid ambiguity, and more strictly applied."192 In the past, it was the providence of a working party, which was created by the Council, to determine whether GATT criteria for an FTA were met. In contrast, under the WTO rules, a Committee of Regional Trade Agreements (CRTA) has taken over this task. ${ }^{193}$ However, the same ambiguities and contradictions stemming from

186 See Kerry A. Chase, Multilateralism Compromised: The Mysterious Origins of GATT Article XXIV (May 2005) (unpublished manuscript, on file with Tufts University), http://ase.tufts.edu/polsci/faculty/chase/multilateralism.pdf (citing WTO, WTO: REgIONALISM AND THE WORLD TRADING SYSTEM 63 (1995)).

187 Chase, supra note 186.

188 See HOEKMAN \& KOSTECKI, supra note 181.

189 Id. (citing GATT Focus, Dec. 1991).

190 HoEKMAN \& KOSTECKI, supra note 181, at 353 (citing FREE TRADE AREAS AND US TRADE POLICY (J. Schott ed., Institute for International Economics, 1989)).

191 Chase, supra note 186.

192 Id.

193 HoEKMAN \& KosteCKI, supra note 181, at 353. 
GATT remain in place under the WTO rules. ${ }^{194}$

Moreover, because of the inherent ambiguities and contradictions of Article XXIV, GATT contracting parties were allowed to develop further exceptions to Article XXIV by creating special provisions intended to promote trade with developing countries. These exceptions to Article XXIV were created with the addition of Part IV in $1965^{195}$ and the Enabling Clause in 1979. ${ }^{196}$ In 1965, the contracting parties added Part IV, Trade and Development, to GATT. ${ }^{197}$ Pursuant to the special provisions of Part IV, GATT now gives high priority to the reduction or elimination of tariffs on the products of least developed countries (LDCs), refrains from introducing tariffs and non-trade barriers (NTBs) to such imports, refrains from imposing internal taxes that would discourage consumption of primary products from LDCs, and does not require reciprocal commitments from LDCs. ${ }^{198}$ In 1979, Part IV of GATT was further expanded by the previously mentioned Enabling Clause, which consolidated the concepts of differential and more favorable treatment for developing countries and economies, and provided the principle of non-reciprocity in trade. ${ }^{199}$ The Enabling Clause enabled developed countries to

194 Id. at 353-54.

195 GATT, part IV, arts. XXXVI-XXXVIII.

196 Enabling Clause, supra note 18.

197 See WTO, The World Trade Organization: A Training Package (1998), http://www.wto.org/english/thewto_e/whatis_e/eol/e/wto01/wtol_17.htm [hereinafter WTO: Training]:

The General Agreement on Tariffs and Trade (both GATT 1947 and GATT 1994) contains a special section, in its Part IV, called "Trade and Development." This section, added in 1965, recognizes the need for a rapid and sustained expansion of the export earnings of the less-developed countries. To this effect, developed countries are called upon to take a number of best endeavor commitments. These include according high priority to the reduction and elimination of barriers to products currently or potentially of particular interest to the developing countries, including customs duties and other restrictions which differentiate unreasonably between such products in their primary and in their processed forms. Part IV codifies in the multilateral trading system the concept of non-reciprocity in trade negotiations between developed and developing countries. Id.

198 See E. Kwan Choi, Faculty Page, Department of Economics, Iowa State University, http://www.econ.iastate.edu/classes/econ355/choi/gatt.htm.

199 WTO: Training, supra note 197. 
accord differential and more favorable treatment to developing countries as a departure from the MFN Clause. ${ }^{200}$

As a result, GATT contracting parties produced two important exceptions to the requirements of Article XXIV. First, developed countries were allowed one-way partial tariff preferences to developing countries through an Article I exemption. ${ }^{201}$ Second, the Enabling Clause allowed two-way partial tariff preferences between developing countries under the Generalized System of Preferences (GSP). ${ }^{202}$ Therefore, the multilateral world trading system produced three categories of FTAs: (1) Article XXIV arrangements involving FTAs and CUs; (2) Enabling Clause arrangements limited to developing countries and permitting partial preferences; and (3) Generalized System of Preferences (GSP) arrangements permitted via a grant of an exception to Article $1 .^{203}$

GATT contracting parties essentially created de facto FTAs, which are not definable as de jure FTAs for purposes of Article XXIV. Thus, these FTAs are not subject to the requirements of Article XXIV, especially its requirements concerning trade barriers to "substantially all the trade." 204 Consequently, developing economies may now, by virtue of the loophole in Article XXIV, invoke WTO rules allowing them to establish FTAs or CUs that do not conform to the requirements of Article XXIV. $^{205}$ The Enabling Clause effected the removal of the "substantially all the trade" test, while allowing for preferences between developing economies. ${ }^{206}$ The latter essentially voided

200 Id. The listed categories of such treatment are:

(a) Preferential tariff treatment accorded by developed contracting parties to products originating in developing countries in accordance with the Generalized System of Preferences;

(b) Differential and more favourable treatment with respect to the provisions of the GATT concerning non-tariff measures governed by the provisions of instruments multilaterally negotiated under GATT (now WTO) auspices. Id.

201 PANAGARIYA, supra note 21 , at 8.

202 Id.

203 Id.

204 Id. at 5-6.

205 HOEKMAN \& KosTECKI, supra note 181, at 355.

206 Id. 
the Article XXIV requirement of full removal of internal trade barriers. ${ }^{207}$ For developing countries, there is a resulting problem of inconsistency between GATT and WTO rules because the requirements of Article XXIV are far more demanding than the Enabling Clause. ${ }^{208}$ This issue deserves special attention, given the prospect of FTAs comprising developing countries and economies, which may be trade diverting and welfare reducing.

In addition, the inherent ambiguities and contradictions of Article XXIV implicitly permit trade distortion and thus may legalize trade distortion. A consequence of the WTO rules tolerating trade distortion may lead to growing regionalism, which may pose a threat to the WTO and multilateral trade goals of trade and investment liberalization. Moreover, if WTO rules tolerate closed and unilateral models of regionalism, then such rules foster models of regionalism that may have a greater proclivity to produce trade distortion and threaten multilateral trade. In terms of GATT or the WTO, the critical issue is ascertaining the line between models of regionalism that complement multilateral trade, and models of regionalism so "distortionary" in nature that the international trading system should no longer tolerate them. ${ }^{209}$ The inherent problems of the WTO rules governing FTAs, such as Article XXIV, are only exacerbated by the growing trend of regionalism and the proliferation of FTAs, such as the proposed ASEAN-China FTA.

\section{E. Exclusionary FTAs}

While the WTO Doha Development Agenda struggles towards

207 Id.; see also PANAGARIYA, supra note 21, at 5. "PTAs have, nevertheless, been accommodated into GATT through Article XXIV, which allows Members to form such arrangements provided they eliminate, rather than just lower, within-union trade barriers on 'substantially all the trade.' The arrangements must also not raise trade barriers on goods produced outside the union." Id. at 5 . However, "trade barriers such as antidumping, which are permitted by other provisions of GATT, can be maintained within the union." $I d$. at 5 , note 6 .

208 PANAGARIYA, supra note 21 , at 6.

209 Killion, supra note 105 . "In terms of GATT, or the WTO, the critical issue is ascertaining the line between governmental measures that are often taken for legitimate domestic policy reasons, and measures so predatory in nature that the international trading system should no longer tolerate them. The question of unilateralism is not well regulated by either GATT or the WTO." Id. at 79. 
implementation, there are increasing numbers of FTAs. ${ }^{210}$ Between 1990-1994, the number of FTAs substantially jumped, with twenty-nine new FTAs reported to the WTO. ${ }^{211}$ From 19951999, the number of FTAs grew by an additional sixty-four agreements, twenty-eight involving transition economies. ${ }^{212}$ After 2000, FTAs between developing countries (South-South agreements), and not FTAs between developed countries (NorthNorth agreements) or FTAs between developed and developing countries (North-South agreements), constituted a large percentage of the new FTAs reported to the WTO. ${ }^{213}$ In a three-year period (2000-2002), there was a fifty-five percent growth in the number of new FTAs. ${ }^{214}$ The WTO estimates that there will be over 300 such regional trade arrangements by $2007 .^{215}$

The proliferation of FTAs poses a threat to the WTO goal of free trade because political motivations for entering FTAs may override economic considerations. ${ }^{216}$ Regionalism is not a problem in and of itself; it can be a building block towards greater trade liberalization. ${ }^{217}$ However, regional trade arrangements can also create more costly and complex trade regimes. ${ }^{218}$ For example, FTAs, and the associated growing costs and administrative burdens resulting from the number of different customs rules of origin, tariff schedules, and regulatory standards,

210 See Andrew L. Stoler, Preferential Trade Agreements and the Role and Goals of the World Trade Organization 2 n. 4 (2004) (on file at the Institute for International Business, Economics \& Law, University of Adelaide).

211 WTO, WORLD TRADE REPORT 47 (2003), http://www.wto.org/english/res_e/ booksp_e/anrep_e/world_trade_report_2003_e.pdf.

212 ld.

213 See Stoler, supra note 210, at 2-3 (citing WORLD Trade REPORT 2003, 47 tbl.IB.9 (2003)); see also WTO.org, Regional Trade Agreements: Facts and Figures, http://www.wto.org/english/tratop_e/region_e/regfac_e.htm.

214 Stoler, supra note 210.

215 Id.

216 See National Foreign Trade Council, Vision 2005: Free Trade and Beyond, Recommendations for the Doha Development Agenda, May 22, 2002, http://www.nftc.org/default/trade/NFTC_Doha_Round_Position_Paper_May_2002.pdf [hereinafter Vision 2005] (discussing the NFTC's "vision for the Doha agenda").

217 See generally J. Frankel, Regional Trading Blocs in the World Economic System, Washington, D.C., Institute for International Economics (1997) (discussing the benefits of regionalism).

218 Vision 2005, supra note 216. 
have proven particularly problematic for developing countries. ${ }^{219}$ FTAs will result in tariff-free zones "throughout important regions of the world while leaving high tariffs and other barriers in place in other regions." 220 A growth in regionalism may pose a threat to multilateral trade because of participating economy preferences to keep the benefits gained from more limited and exclusionary preferential trade arrangements. ${ }^{221}$

The debate contrasting regionalism with multilateralism has yet to be resolved. ${ }^{222}$ Some critiques perceive liberalization as the cause of social and economic problems, rather than the solution. ${ }^{223}$ In this respect, Asian regional bodies adopted an incorrect model by adopting a neo-liberal agenda. ${ }^{224}$ Other criticisms simply center on the adoption of economic liberalization or neo-liberalism. ${ }^{225}$ This is mostly an issue of state sovereignty that results from models of regionalism embracing both developed and developing economies. $^{226}$ Some development theorists, in challenging liberalization as the best option, argue that the retention of state control over strategic economic instruments and sectors provides more options for development. ${ }^{227}$ There are also criticisms that focus on economic liberalization, in terms of whether it is desirable, while others direct attention to a desirability that is contingent upon the context in which liberalization is to occur. ${ }^{228}$ Some critics, such as liberal economists, encourage a multilateral approach rather than a regional approach to trade liberalization. ${ }^{229}$

219 Id. at 1 .

$220 \mathrm{Id}$.

221 Id. at 2.

222 See generally PANAGARIYA, supra note 21, at 47-111 (discussing preferential trade areas and multilateralism).

223 See Paul Bowles, APEC: Progress Based on the Wrong Model?, 6 CAN. Bus. ECON. 48 (1997) (discussing different definitions for regional blocs).

224 Id. at 52.

$225 \mathrm{Id}$.

226 Id.

227 Id. at 52.

228 See PANAGARIYA, supra note 21 , at 13 . One school of thought is that there is minimal trade diversion risk when union members are "Natural Trading Partners," that is, they already trade with each other and are geographically proximate. However, economists often criticize this view. Id.

229 See Bowles, supra note 223. 
For such critics, regionalism is a second best choice after multilateralism. ${ }^{230}$

Supporters of multilateral trade and regionalism that complements multilateral trade are concerned with the plight of developing economies excluded from the larger free trade arrangements, either by choice or geography. ${ }^{231}$ However, as a developing country, China presents an anomaly, because it proposes the world's largest FTA, comprising solely developing Asian economies. A related question involves the role of economics and/or politics as motivation for Chinese policy. In terms of the feasibility of Asian regionalism, most critiques focus on the viability of market-led cooperative regionalism, as seen in thematic discourses addressing FTAs and RTAs. ${ }^{232}$ However, the 2004 ASEAN-China Accord may present a non-market cooperative form of regionalism, constituting a model motivated by political considerations that could pose an economic and security threat to the Asia-Pacific region.

The world has witnessed a growth in both FTAs motivated solely by political considerations and FTAs motivated by a combination of economic and political considerations. If motivations for FTAs are grounded in political considerations, then the WTO may lose its appeal as a feasible alternative. ${ }^{233}$ For example, political motivations were behind the negotiations of the U.S.-Israel, U.S.-Jordan, and U.S.-Morocco FTAs. In addition, the Mercosur Agreement (South American Common Market, Mercado Común del Cono Sur or Southern Cone Common Market) linking Brazil, Argentina, Uruguay, and Paraguay was an agreement motivated by political considerations. ${ }^{234}$ FTAs

$230 I d$

231 Vision 2005, supra note 216.

232 See Warwick J. McKibbin \& Wing Thye Woo, The Consequences of China's WTO Accession on Its Neighbours (Oct. 18, 2002) (CEDS paper, on file with the University of Michigan), http://www.wdi.bus.umich.edu/CEDSpapers/Woo_Wing Thye.pdf.

233 Id. at 6-11.

234 See Página Oficial del MERCOSUR (Official Page of the Mercosur Secretariat), http://www.mercosur.org.uy/; see also The EU's Relation with Mercosur-Overview, http://europa.eu.int/comm/external_relations/mercosur/intro/ ("The Mercosur was created by Argentina, Brazil, Paraguay and Uruguay in March 1991 with the signing of the Treaty of Asuncion. It originally was set up with the ambitious goal of creating a common market/customs union between the participating countries. . . A transition 
motivated entirely or in part by political considerations can have a negative national and global effect in terms of economics. ${ }^{235}$ Such FTAs may result in trade diversion, which is welfare reducing. ${ }^{236}$ Generally, FTAs grounded in exclusionary motivations present the danger of being neither welfare enhancing nor complementary to the WTO multilateral process, as participants will have little interest in seeing progress at the multilateral level. ${ }^{237}$ However, exclusionary FTAs primarily motivated by political considerations, as opposed to economic considerations, have greater potential to threaten multilateral trade. The proposed ASEAN-China FTA, comprising developing economies, is motivated solely by political considerations and thus poses a threat to multilateral trade.

The question of whether an exclusionary FTA threatens multilateralism is an issue of trade creation and welfare enhancement rather than trade diversion and welfare reduction. In terms of liberalization, diversion is the welfare change caused by consumers and producers substituting higher cost imports from an exporting economy for lower cost imports from third-world economies. $^{238}$ High-cost domestic production in one economy replaced by lower-cost production in another economy creates welfare improvement known as trade creation. ${ }^{239}$ Therefore, trade creation allows aligned countries to better exploit their comparative advantage. ${ }^{240}$ In terms of more liberalized trade,

phase was set to begin in 1995 and to last until 2006 with a view to constituting the common market.").

235 McKibban \& Woo, supra note 232, at 6-11.

236 See Shujiro Urata, Towards an East Asia Free Trade Area, OECD Development Centre, Policy Insights \#1, 3 (Mar. 2004), http://www.oecd.org/dataoecd/36/55/ 31098183.pdf.

237 McKibban \& Woo, supra note 232, at 6-11.

238 See generally Jacob Viner, The Customs Union Issue, New York: Carnegie Endowment for International Peace (1950) (introducing the concepts of trade creation and trade diversion).

239 See Szepesi, supra note 174 , at 8.

240 Id.; see also Richard N. Block, Karen Roberts \& Russell Ormiston, Economic Perspectives on International Labor Standards, 11 MSU-DCL J. INT'L L. 417, 419 (2002).

Traditionally, economists have referenced the "factor cost model" when discussing international trade. Specifically, the theory suggests that countries should specialize in the production of goods in which they can produce at least 
economies are able to further specialize their production, which allows them to provide the products to the markets of aligned economies at lower prices. ${ }^{241}$ Trade creation, in terms of FTAs, improves resource allocation and welfare. ${ }^{242}$ Whether or not trade creation outweighs trade diversion determines whether aligned economies will result in an overall net static welfare gain in an economy. ${ }^{243}$

One problem with FTAs is that they do not necessarily generate gains from trade. An FTA employing a partial, if not discriminatory, reduction in trade barriers, although shifting sources of supply, ultimately still discriminates between sources. $^{244}$ While gains can occur when production in an aligned economy displaces higher cost domestic production, the reverse effect, trade diversion, results when an aligned economy displaces lower cost imports from non-aligned economies. ${ }^{245}$ In terms of imports, FTAs between aligned developing economies tend to generate trade diversion rather than trade creation. ${ }^{246}$ Assuming homogenous goods, trade diversion will ensue when aligned developing economies are burdened with domestic consumer prices that are fixed at world prices and import trade tariffs. ${ }^{247}$ While the absence of an import tariff in aligned economies will increase production, aligned economies will substitute cheaper imports from non-aligned economies with more expensive aligned economy imports. ${ }^{248}$ The result is welfare-reducing trade

cost. ... Theorists take into account a country's productive factor endowments, including land, capital, labor and climate. In applying the factor cost model, economists compare the costs of production of each product both within and between countries. When a jurisdiction has the capability to produce a particular product at least cost compared to other jurisdictions, it is said to have an "absolute advantage." Meanwhile, that country is said to have a "comparative advantage" in a certain product if it can produce that output cheaper relative to other products within its boundaries. Id.

241 See Szepesi, supra note 174 , at 8.

242 Id.

243 Id.

244 ld.

245 Regional Integration Agreement, supra note 5, at 40.

246 Id. at 90.

247 Id. at 42.

248 Id. at 42 (citing Maurice Schiff, Small Is Beautiful: Preferential Trade Agreements and the Impact of Country Size, Market Share, and Smuggling, 12 J. Econ. 
diversion. $^{249}$

FTAs comprising aligned developing economies present other problems. In particular, there is the problem of income convergence versus divergence. ${ }^{250}$ Generally, such FTAs show a proclivity towards divergence of their real incomes. ${ }^{251}$ In contrast, aligned developed economies tend to cause real income levels to converge. ${ }^{252}$ This effect is mostly attributable to the phenomenon that economies with comparative advantages closer to the world average, rather than extreme comparative advantages, experience better performance in FTAs. ${ }^{253}$ In FTAs, those economies that manifest extreme comparative advantages, rather than those closer to the world average, create the risk of switches in import suppliers. ${ }^{254}$ Wedging intermediate economies between an economy with extreme comparative advantage and economies closer to the world average tends to distort the extreme economy's trade, that is, switches in supply economies. ${ }^{255}$ In such an instance, trade with the world as well as with an economy with an extreme comparative advantage presents less close substitutes, therefore enhancing the probability of trade diversion. ${ }^{256}$ Notwithstanding comparative advantages, the forces of agglomeration and the flow of information equally tend to cause income divergence in FTAs of developing economies. ${ }^{257}$

The force of agglomeration bears mention because of the disparity in economic development between China's coastal regions and western provinces. ${ }^{258}$ The development of economic

INTEGRATION 359 (1997)).

249 Regional Integration Agreement, supra note 5, at 40.

250 Id. at 51-61.

251 Id.

$252 I d$.

253 Id.

254 Regional Integration Agreement, supra note 5, at 55.

255 Id.

256 Id. at 56-58.

257 Id.

258 See HuIJIONG, supra note 129; see also Accession to WTO Delivers $\$ 40$ Billion a Year to China's Economy But Gains Unevenly Shared: World Bank Study, World Bank: News and Events, Feb. 21, 2005, http://www.worldbank.org.cn/English/content/747 j63205722.shtml [hereinafter World Bank Study]. 
centers calls into play a phenomenon known as the "cumulative causation mechanism," which leads to clustering, or agglomeration, of economic activity. ${ }^{259}$ Spatial clustering of economic activities, such as electronics in Silicon Valley, cinema in Hollywood, and auto manufacturing in Detroit, is common in many cities. ${ }^{260}$

In terms of manufacturing industries, clustering or agglomeration is a by-product of the interaction between "centripetal" forces that encourage firms to locate in close proximity, and "centrifugal forces," such as "congestion, pollution, or other negative externalities that might be associated with concentrations of economic activity" that will encourage firms to spread out. ${ }^{261}$ Generally, firms want to locate near customers, and likewise, customers want to be closer to their suppliers. ${ }^{262}$ However, "pulling in the opposite direction are 'centrifugal forces,' encouraging the dispersion of activity."263

Market liberalization and other reforms associated with China's accession to the World Trade Organization (WTO) are delivering gains worth more than $\$ 40$ billion a year to China's economy, and adding about $\$ 75$ billion a year to real incomes worldwide, says a World Bank study. But the same report recommends that China make policy adjustments to balance the uneven distribution of benefits of these gains between the country's rural and urban regions. World Bank Study, supra.

259 Anthony J. Venables, Regional Integration Agreements: A Force for Convergence or Divergence? 15 (World Bank Pol'y Res., Working Paper No. 2260, 1999) ("Developing countires may be better served by 'north-south' than by 'southsouth' free trade agreements. Free trade agreements between low income countries tend to lead to divergence in member country incomes, while agreements between highincome countries tend to lead to convergence.").

260 Id.

261 Id. at 15-16.

The centripetal forces are usually classified in three groups. The first force is knowledge spillovers, or other beneficial technological externalities that make it attractive for firms to locate close to each other-in Marshall's phrase, "The mysteries of the trade become no mysteries, but are, as it were, in the air." The second group is various labor market pooling effects, which encourage firms to locate where they can benefit from readily available labor skills-perhaps by attracting skilled labor away from existing firms. The third centripetal force arises from "linkages" between buyers and sellers. Id. at 15-16 (citing Alfred Marshall, PRINCIPLES OF ECONOMICS (1920)).

262 Venables, supra note 259 , at 16.

263 Id. For example, industries in the United States are much more spatially concentrated than in Europe (even controlling for the distribution of population and 
Uneven regional development and high spatial concentrations in manufacturing are problematic for China; ${ }^{264}$ examples are manufacturing centers in the Pearl Delta (Zhusan Jiao) in Guangdong Province, and the Long River Delta (Changsan Jiao) on the outskirts of Shanghai. ${ }^{265}$

In terms of FTAs and problems of income convergence versus divergence, the issue is one of balancing the centripetal and

manufacturing as a whole), suggesting that regional integration in Europe could cause agglomeration at the sectoral level (for example, Germany gets engineering, the UK financial services, and so on). The possibility that this might happen is generating some concern in Europe, although evidence for it is so far rather weak. Regional Integration Agreement, supra note 5, at 58 (citing H. G. Midelfart-Knarvik, S. Redding Overman \& Anthony J. Venables, The Location of Industry in Europe, Center for Economic Policy Research, London (1999)).

264 François Gipouloux, Integration or Disintegration? The Spatial Effects of Foreign Direct Investment in China, CHINA PERSPECTIVES, May-June 1998, at 6, http://www.cefc.com.hk/uk/pc/articles/art_ligne.php?num_art_ligne=1702. "[T]he coastal provinces, with the exception of Liaoning, stand out from the rest of the country, with a level of investment in industry from foreign-funded companies surpassing $15 \%$ (10\% in Jilian Province) ... . Central and western China remain below this level. . . . The massive re-locations that took place all through the 1990s, first in ASEAN countries and then in the Chinese coastal areas, resulted in a manufacturing crescent, the vocation of which was to reach out to the world and conquer distant markets." Id; see also Huang Ping, China's Rural Migrants Under Uneven Development, 102-117, Soc. SCI. IN CHINA (Zhongguo shehui kexue), Winter 2003 (discussing the problem of a dual system of a rural-urban arrangement) ("In contrast to the dazzling race among metropolises to jiegui ('being geared to international conventions'), rural communities have deteriorated both in scale and content."); see also Masahisa Fujita, J. Vernon Henderson, Yoshitsugu Kanemoto \& Tomoya Mori, Spatial Distribution of Economic Activities in Japan and China, June 9, 2003, at 49-82, http://www.econ.brown.edu/faculty/henderson/JapanChina-ReferencesPaper2.pdf (discussing spatial discrimination and the coast versus the hinderlands) ("China has subsidized FDI (through tax breaks) in prefecture level cities and encouraged FDI and trade development in certain coastal cities, as part of a general program emphasizing coastal development, over hinterland development. The question is whether the FDI policy is efficient."); see also The Spatial Distribution of Economic Activities in Japan and China, Handbook of Urban and Regional Economics (J.V. Henderson \& J-F Thisse eds., 2004).

265 Gipouloux, supra note 264.

All in all, FDI in China has a three-fold effect on regional economic investment. ... [The third effect is that it] encourages integration of the coastal zones into a network of international subcontracting led by the "Four Dragons", Japan and, to a certain extent, American and European companies. These zones are clearly oriented towards exports: what is happening in the Pearl River Delta, the Shanghai-Nanjing-Hangzhou triangle and, to a lesser extent, the Gulf of Bohai is the constitution of a manufacturing crescent aiming to conquer distant markets in Europe or the United States. Id. 
centrifugal forces at work. ${ }^{266}$ One problem is that an FTA membership may amplify or cause the clustering of economic activity, resulting in widening income differentials between aligned economies. The probability that this will occur is enhanced by the fact that in China, manufacturing as a whole is generally clustered in a few locations, thus, "deindustrializing the less favored regions." 267 Such patterns of clustering are likely to lead to divergence of the income levels of members of an FTA. ${ }^{268}$ The same result holds true for a country, such as China, whose basic industrial infrastructure-transport, transport, telecommunications, access to financial markets, and other business services-is thinly developed and most importantly, unevenly spread. ${ }^{269}$ In addition, clustering "will be more likely to occur with preferential trade liberalization-an FTA-than with general import liberalization.,"270 Consequently, "[t]his leads to the strong result that FTAs between low income countries will tend to cause divergence of their income levels, whereas FTAs between high income levels will lead to convergence."271

Notwithstanding comparative advantage and agglomeration, the force of knowledge flows can also cause the performance of

266 Venables, supra note 259 , at 15.

267 Id. at 18.

$268 I d$. at 18-19. In south-south FTAs clustering patterns are likely to be reinforcing. For example, as Nairobi, Abidjan and Dakar have attracted manufacturing, so they have started to develop business networks and the linkages that tend to lock manufacturing in to the location. The process might be further accelerated by the propensity of foreign direct investment to cluster in relatively few locations. Agglomeration then accentuates the comparative advantage forces for divergence. $I d$. at 18 .

269 Id. at 18. Income divergence is also more likely to occur-if manufacturing as a whole is a small share of the economy, "because fitting the whole of manufacturing in one (or a few) locations is then less likely to press up against factor supply constraints and lead to rising prices of immobile factors (such as land)." Id.; see also Stephen Roach, The Challenge of China and India, FIN. TIMEs, Aug. 31, 2004, http://win.mofcom.gov.cn. However, in China, the manufacturing sector constitutes a 53 percent share of the economy. Id.

270 Venables, supra note 259, at 18 ("This is because an FTA is inherently more inward looking, strengthening linkages between firms in the FTA, so increasing one of the centripetal forces.").

271 Id. at 20 ("The analysis suggests that developing countries are likely to gain more from FTAs with high income countries, where there are better prospects for convergence with the other-high income-members."). 
members of developing country FTAs to diverge. ${ }^{272}$ However, FTAs can promote knowledge flows between aligned economies, such as transfers of technology, when comprising developed economies with high incomes. ${ }^{273}$ There are clear implications that increasing trade with high-income countries by forming a NorthSouth FTA, rather than South-South FTA, "may lead to beneficial transfers of technology, and consequent convergence of incomes." 274 Comparatively, aligned developing economies do not offer such good prospects, especially when they are relatively closed to external trade and are trade diverting. ${ }^{275}$

Conversely, assuming net trade creation rather than diversion, CUs or FTAs, such as NAFTA, should enjoy greater economic efficiency and benefits stemming from increased trade and investment. $^{276}$ The United States Trade Representative has even advocated FTAs as triggering "competitive liberalization" and as an alternate route to free trade with economies competing to open markets to each other. ${ }^{277}$ A fear of exclusion serves as an impetus for nonmembers to either join the group or accept broader agreements. ${ }^{278}$ However, political motivation in part or in entirety engenders a tacit assumption of trade diversion. FTAs motivated solely by politics are neither welfare enhancing, nor complementary to the WTO and multilateralism. ${ }^{279}$ Thus, models of regionalism motivated by political considerations threaten multilateral trade and, most importantly, produce trade distortion

272 Regional Integration Agreement, supra note 5, at 59-61 ("Increasing trade with high-income countries by forming a North-South RIA may lead to beneficial transfers of technology, and consequent convergence of incomes.").

273 Id. at 59-60.

274 Id.

275 Id. at 61.

276 See generally James E. Meade, THE THEORY OF CUSTOMS UNION (1955); see also generally Viner, supra note 238; Kym Anderson, The Challenge of Reducing Subsidies and Trade Barriers 4 (World Bank Pol'y Res., Working Paper No. 3415, 2004).

277 Soamiely Andriamananjara, On the Relationship Between Preferential Trade Agreements and the Multilateral Trading System, Remarks prepared for the PECC Trade Forum Meetings at the Institute for International Economics, Washington, D.C., 3 (Apr. 22, 2003), http://www.pecc.org/publications/papers/trade-papers/1_SII/6-andria mananjara.PDF.

278 Id.

279 Stoler, supra note 210 , at 4. 
and are welfare reducing. ${ }^{280}$

A problem of FTAs, such as NAFTA, Mercosur, and the European experiment that was clearly motivated by political considerations, ${ }^{281}$ is that they "inevitably politicize trade more than multilateral trade agreements do."282 However, what distinguishes Chinese regionalism from other FTAs is a proposed ASEANChina FTA comprising only developing economies. China is a developing country, as opposed to a least-developed country, thus avoiding any arguable exceptions to the general theory prognosticating a welfare reducing effect. ${ }^{283}$ Notwithstanding an exception to the general theory of the welfare effect of trade distortion, ${ }^{284}$ the advent of a politically motivated ASEAN-China FTA, as the world's largest FTA, will likely produce trade distortion in the global economy-assuming arguendo the world's largest FTA could produce immeasurable and exponentially growing welfare reducing effects.

FTAs between developing economies and the poorest economies, such as the proposed ASEAN-China FTA, present a host of potential problems. ${ }^{285}$ Typical trade areas comprising subsets of nations are not necessarily welfare enhancing for all participating nations. ${ }^{286}$ Notwithstanding causes and effects of

280 See Edward J. Lincoln, Taking APEC Seriously 6 (Brookings Institute, Policy Brief No. 92, Dec. 2001), http://www.brookings.edu/comm/policybriefs/pb92.htm.

281 See J. F. Francois \& M. Rombout, Preferential Trade Arrangements, Induced Investment, and National Income in a Heckscher-Ohlin-Ramsey Model 2 (Tinbergen Institute, Discussion Paper TI 2000-061/2, June 2000), http://www.tinbergen.nl/ discussionpapers/00061.pdf.

282 Jagdish Bhagwati, Free Trade TODAy 110 (2002).

283 See id. (discussing the theory that free trade might not be best policy for LDCs that are facing what economists refer to as a market distortion); see also WTO, Understanding the WTO: The Organization, Least Developed Countries, http://www.wto.org/english/thewto_e/whatis_e/tif_e/org7_e.htm ("The WTO recognizes as least-developed countries (LDCs) those countries which have been designated as such by the United Nations. There are currently [fifty] least-developed countries on the UN list, [thirty-two] of which to date have become WTO members.").

284 Anderson, supra note 276, at 2.

285 PANAGARIYA, supra note 21, at 126 (“'[B]oth economics and politics are against a discriminatory bloc in East Asia. Historically, East Asia has benefited greatly from an open world trading system. The region's future interests will continue to be served by a strategy, which ensure an open world trading system.").

286 Andriamananjara, supra note 277. 
trade distortion, such as import issue and real distortion, the harm from discrimination in trade affects exports to an FTA market as well as the terms of trade, which include decreased export prices required to maintain competitiveness in a preferential market. ${ }^{287}$ An FTA, particularly its discriminatory nature, has the potential to adversely affect the poorest economies. ${ }^{288}$ Moreover, trade distortion stemming mostly from non-participants in the global economy will adversely affect aligned developing countries, especially the poorest economies in an FTA, as well as the global economy. ${ }^{289}$

A politically motivated FTA may also pose a threat to regional security for China. The region known as the Asia-Pacific does not include South Asia (India, Pakistan, Afghanistan, Bangladesh, and Sri Lanka), or Southwest Asia (the Arab Peninsula, Iraq, and Iran). ${ }^{290}$ Instead, the Asia-Pacific refers to the region comprising East Asia and Southeast Asia, two major socio-geographical subsets (along with Oceania, North America and South America), all constituting the Pacific Basin. ${ }^{291}$ It is a region that is larger than Europe. ${ }^{292}$ However, without undertaking a lengthy analysis of the security threat to such a large region, ample examples are available in the sub regions of the Pacific Basin. ${ }^{293}$

Taiwan presents one such case. The pending crisis over crossstrait relations between Beijing and Taipei is a prime example. Although Taiwan is an Asian government, a growing proliferation of China-led FTAs may threaten its economic liberalization. Taiwan may well be dependent on Asia-Pacific Economic Cooperation (APEC) to support its economic liberalization. ${ }^{294}$ The

287 Id.

$288 \mathrm{Id}$.

289 Id. at 8.

290 See Tan Tai Yong, The Post-War History of East and Southeast Asia, AsıEUROPE ENVIRONMENT FORUM, http://www.asef.org/asef-uni/3_infohub/infohub_m_ library.html.

291 Id.

292 Id.

293 Lai I-Chung, Taiwan Needs an APEC Strategy (Perry Svennson trans.) TAIPEI TimES, Nov. 15, 2004, http://www.taipeitimes.com/News/editorials/archives/2004/11/ 15/2003211174; see also Asia-Pacific Economic Cooperation: Member Economies, http://www.apec.org/apec/member_economies.html.

294 See Lai, supra note 293. 
distinctive Chinese model of globalization (quanqiuhua) may pose a political threat to its economic liberalization. ${ }^{295}$ Additionally the proliferation of FTAs in the Asian region seems to be excluding Taiwan. ${ }^{296}$ While the Beijing-Taipei debate continues, Asian and non-Asian nations are economically and politically aligning themselves with China. ${ }^{297}$ This exclusion runs contrary to the spirit of open regionalism that is exemplified by APEC, a model of regionalism that seeks to complement, and not threaten, global trade and the WTO. ${ }^{298}$ In terms of APEC, open regionalism is generally defined as a concerted and unilateral trade liberalization that is along the lines of the MFN status. ${ }^{299}$ Taiwan faces the threat of Beijing building an Asian strategic order centered on China, because Beijing remains highly sensitive about the de jure and de facto recognition of Taiwan's legitimacy through participation in regional and international dialogues. ${ }^{300}$ For example, there are the Boao Forum for Asia and the Shanghai Cooperation Organization, both of which were established by China, and exclude Taiwan. ${ }^{301}$ In addition, China is employing the six-nation talks addressing the North Korean nuclear issue for purpose of redefining strategic positions of the United States,

295 ld.

296 Id.

297 See id.

298 Id.

299 See id.

300 JiNG-dong YUAN, Asia-PaCifiC SECURITY: China's Conditional Multilateralism AND GREat POWER ENTENTE 16 (2000), http://www.carlisle .army.mil/ssi/pubs/2000/asiapac/asiapac.pdf.

301 Lai, supra note 293; see also Backgrounder: Chronology of Boao Forum for Asia, PeOPle's DaIly OnLINE, June 25, 2004, http://english.people.com.cn/200404/23/ eng20040423_141356.shtml ("Feb. 27, 2001: The BFA was officially established, with the Declaration on the BFA adopted by delegates from 26 founding member countries. Chinese President Jiang Zemin addressed and presented a poem to the inauguration ceremony of the BFA."); China.org.cn, China and the Shanghai Cooperation Organization, May 13, 2003, http://www.chinataiwan.org/web/webportal/W5042136/ A5046305.html ("On June 15, 2001, the Shanghai Cooperation Organization (SCO) was established in Shanghai by the heads of state of the six countries of China, Russia, Kazakhstan, Kyrgyzatan, Tadzhikistan and Uzbekistan on the basis of the original "Shanghai Five," signifying the birth of a new regional cooperation organization aiming to seek security through mutual trust and to seek cooperation through mutual benefit."). 
Japan, and South Korea on the Korean Peninsula. ${ }^{302}$ No doubt, most realize that China has the capability of reining in Kim Jong Il, if it so elects. ${ }^{303}$ It has even been suggested that China derives a "psychological satisfaction from watching Pyongyang's nuclear roguery stymie Japan and the United States."

In addition, the ASEAN nations, which are representative of nations in this sub-region, perceived security threats posed by China. ${ }^{305}$ China's domination of the Asian region through economic, political, and especially military coercion is problematic. $^{306}$ China's rising economic power in Asia has evolved into a rising military power, or at least increased fears of a Chinese military presence in the Asian region. ${ }^{307}$ According to Singapore Defense Minister Teo Chee Hean, China and India have "aspirations to be regional, if not global, powers." gains economic power, China continues to reshape the geopolitical contours of the Asian region. ${ }^{309}$ A primary concern for many is that the United States and China may become locked in an adversarial relationship concerning regional peace and security, because many deem China ambitious enough to dominate the Asian region. ${ }^{310}$

302 Lai, supra note 293; see also Upcoming Six-nation Talks in Jeopardy, AsIA NEws, Sept. 16, 2004, http://www.asianews.it/view.php?l=en\&art=1489. Although talks did eventually resume, China's initial response was perceived as follows, "Until concrete evidence is produced China-the main go-between in the six-nation talks-has declined making any comment." Upcoming Six-Nation Talks in Jeopardy, supra.

303 Victor Davis Hanson, The Global Shift, NAT'L Rev. Online, Jun. 10, 2005, http://www.victorhanson.com/articles/hanson061005.html.

304 Id.

305 See, e.g., Strange bedfellows at the UN: Growing Asian worries over PRC power, CHINA REFORM MONITOR No. 597, Aug. 12, 2005, http://www.afpc $.0 r g / \mathrm{crm} / \mathrm{crm} 597 . \mathrm{shtml}$.

306 Id.

307 Id.

308 Id. at para. 4.

309 See Potential Chinese dominance of North Korea: New anti-secession law pressures Taiwan, ChINA ReFORM MONITOR No. 572, Dec. 21, 2004, http://www.afpc .org/crm/crm572.shtml (noting that China is ambitious to dominate Asia and discusses examples involving North Korea and Taiwan).

310 See id.; see also White Paper Maps Military's Future, PeOPle's DaILy OnLINE, Dec. 28, 2004, http://english.people.com.cn/200412/28/eng20041228_168913.html ("But the old security problems in the region have not been fundamentally removed 
In terms of exclusionary FTAs, which are most problematic for non-Asian economies with the advent of a growing interest in regionalism and a perceived weak APEC, Asian nations are actively pursuing regional dialogues to the exclusion of non-Asian economies. $^{311}$ In light of a perceived weak and ineffective APEC, Asian nations started turning to ASEAN, or ASEAN Plus Three, and FTAs between Asian nations, ${ }^{312}$ such as the 2004 ASEANChina Accord. The growth of Asian FTAs, especially the new potential of Asian regionalism proposed by ASEAN at the Tenth ASEAN summit, may pose a threat to multilateral trade and the WTO. The ASEAN summit struck an accord between China and ASEAN that could result in the largest FTA in the world.

\section{China-Led Regionalism}

The Western world should not be dismayed by China's geopolitical posturing through the vehicle of Chinese regionalism (quyu zhuyi). The concept of China's "new regionalism" (xin quyu zhuyi) was in part borrowed from Western models of FTAs, such as the European Union and NAFTA. ${ }^{313}$ The European Union is considered by many to be a model for regionalism, especially in its formal institutionalization and progression from FTA to economic union. ${ }^{314}$ However, China shuns many of the positive aspects of the more orthodox models of regional integration because political considerations and geopolitical posturing in the Asian region primarily motivate Chinese regionalism.

Some analysts say China is developing a variant to the

while new insecure elements are emerging. The United States is realigning and beefing up its military presence in the region and strengthening military alliances.").

311 See Lincoln, supra note 280.

312 Id.

313 See Tianshu Liu, Implication of Trade Creation and Trade Diversion Effect on Trade between RTAs and China and Australia, Proceedings of the 16th Annual Conference of the Association for Chinese Economics Studies, Brisbane, Australia, Jul. 19-20, 2004, at 2, http://www.uq.edu.au/economics/acesa2004/pro/Liu.pdf.

314 See generally Bela Balassa, The Theory of Economic Integration (1961) (discussing a model of integration that progresses from agreement of states (FTA) to customs union, then to economic union); see also Regionalism and World Order (Andrew Gamble \& Anthony Payne eds., 1966) (comparing other models of regionalism with the EU model). 
European Union model, or Western model, of regionalism. ${ }^{315}$ China may eventually demonstrate to a multilateral-inclined, free trade world the difference between traditional and West-centric trade methodologies and the praxis of FTAs with Chinese characteristics. In its bid to be a world player, China extended the country's growing economic powers to form an entire region of international political power. Many sources, especially economic assessments of China's economic performance, seem to ignore the geopolitical forces accompanying China's intent to broaden Asian regionalism, while also making it more exclusive, perhaps characterized as an Asia-only club. ${ }^{316}$ Creating such a distinctive club entails consequences that are political and result in China situating itself as the political leader in the Asia region. Prime examples of such problems include the previously mentioned pending crisis over cross-strait relations with Taiwan and the six-

315 See, e.g., Asia Strategic Forum's Mt. Kumgang Conference "Whither the Six Party Talks on North Korea: A Prelude to the Asian Century or a Footnote to the War on Terrorism?," Institute for International Policy, University of Washington, Mt. Kumgang, North Korea, June 10-12, 2005, http://www.iip.washington.edu/pdf/Mt-KumgangProceedings-090905.pdf [hereinafter Mt. Kumgang Conference] ("In fact, the growth of anti-Americanism spurred in part Washington's East Asia policies has motivated many East Asian countries toward a narrower form of regionalism that the majority believed to be detrimental to fuller integration as well as to U.S. strategic interests."); see also Baldwin, supra note 7 ("The Domino theory predicts that either will produce an East Asia wide free trade area for manufacturers, but with different endpoints.").

316 See Mt. Kumgang Conference, supra note 315 ("However, the upcoming formalization of ASEAN + Three into the East Asian Community sparked renewed fears among several conference analysts of an exclusive grouping that will be detrimental to regional integration (full global integration) and as well as U.S. strategic interests."); see also Eric Teo Chu Cheow, China as the Center of Asian Economic Integration, Ass' N FOR ASIAN RES., Aug. 6, 2004, http://www.asianresearch.org/articles/2241.html ("But the East Asian model for economic and monetary cooperation would be less of an institutional model (as in Europe) than a functional one. Whatever its future modality, Asian integration appears to be centered on a China-inspired East Asian growth."); see also M. Ulric Killion, Three Represents and China's Constitution: Presaging Cultural Relativisitic Asian Regionalism, 13 CuRRENTS: INT'L TRADE L.J. 23 (2004).

In terms of regionalism, it is China, more so than any other developing country or economy, that demonstrates the potency of nationalism and embodies possible alternatives to Western conceptions of democracy and capitalism. China is a reminder that history is not close to an end and in that sense it issues a cultural, political, and if one will, ideological challenge to those who entertain especially expansive and dialectic visions of world order. Killion, supra, at 105. 
nation talks addressing the North Korean nuclear issue. ${ }^{317}$

While Western economists and politicians debated the merits and likelihood of success and failure in East Asian regionalism, in terms of ASEAN ${ }^{318}$ and APEC's Bogor goals, ${ }^{319}$ China continued to both engage ASEAN and pursue a regional FTA with ASEAN. To the dismay of the Western world, Asian regionalism now seems a likely probability. However, critics say there is no Asian regionalism based strictly on "fundamental identity or ideology ... [nor is the region] ready for either deep economic integration or political convergence. ASEAN has diluted, comprising six relatively more developed, rich states and four poorer transition economies, forged by politics and security first, scale economies second." ${ }^{320}$ Thus, China is demonstrating to a doubting Western world, the difference between west-centric regional trade taxonomies and the praxis of open regionalism with Chinese characteristics. Moreover, because of an increasing connectedness between China and ASEAN, the fate of sub-regional groupings, such as APEC, became largely intertwined with a Chinese praxis of FTAs with Chinese characteristics.

The ASEAN summit held in Vientiane, Laos in November 2004 forged new trails in terms of Asian regionalism and community building. ${ }^{321}$ This meeting most importantly resulted in the landmark 2004 ASEAN-China accord. ${ }^{322}$ The accord laid the groundwork for the introduction of a possible new rival for APEC. ${ }^{323}$ The future of Asian regionalism, which garnered some support at the Tenth ASEAN summit, may well be what is being

317 REVIEW COMMISSION REPORT, supra note 130, at 5, 15, 101-104.

318 See REgIONALISM AND GLOBAL INTEGRATION: EUROPE, ASIA AND THE AMERICAS 11 (William D. Coleman et. al. eds., 1998); see also REGIONALISM, MuLTILATERALISM, AND THE POlitics OF Global TRADE 10-13 (Donald Barry et. al. eds., 1999).

319 See Sharma, supra note 43, at 37-38 and accompanying text; see also Bogor Declaration, supra note 43.

320 Linda Low, Overview, Comparative Evaluation and Prognosis of Bilateral Trade Agreements (BTAs) in Asia and the Pacific, Economic and Social Commission for Asia and the Pacific (Jan. 30, 2003), http://www.unescap.org/tid/mtg/low.pdf.

321 See 10th ASEAN Summit, supra note 26.

322 Id.

323 See Eric Teo Chu Cheow, Bigger Steps Towards Asian Integration, CHINA DAILY, Dec. 21, 2004, http://www.chinadaily.com/cn/english/doc/2004-12/21/content_ 401932.htm. 
called "JACIK," comprising Japan, ASEAN, China, India, and the Republic of Korea. ${ }^{324}$ India may be the only limitation to forming a "JACIK" FTA. ${ }^{325}$ India is aware that in order to join "JACIK" it will have to obtain the tacit consent of Japan and China. ${ }^{326}$ Moreover, a China-India FTA is "under study."327 As of August 2005, the China Council for Promotion of International Trade (CCPIT) called for expediting a China-India FTA, which alone would encompass two-fifths of the world's population. ${ }^{328}$ The ASEAN-China accord created the prospect for a free trade megazone. ${ }^{329}$ However, an ASEAN-China FTA, in conjunction with a prospective "JACIK" FTA, turned the prospect of a free trade megazone into a potential free trade super megazone.

China is determinedly pursuing a "JACIK" FTA. ${ }^{330}$ In January 2005, China commenced a feasibility study addressing an East Asia Free Trade Area (Dong Meng Ziyou Maoyi $Q u$ ) that includes China, Japan, the Republic of Korea, and the ten member ASEAN nations. ${ }^{331}$ This trade area is expected to reflect the arrangement recently effected with ASEAN. ${ }^{332}$ The background for this model of a broader Asian regionalism dates back to 2003, when China Premier Wen Jiabao initially made the proposal for an East Asia Free Trade Area. ${ }^{333}$ One Chinese source described this process as a gradual and long-term process, which will be established by joint efforts from "relevant" countries. ${ }^{334}$ A future "JACIK" FTA would be an expansion of both the 2004 ASEAN-China Accord and the theme of an Asia-only club, which excludes "nonrelevant" members, such as Australia, Canada, the United States,

324 Id.

$325 \mathrm{Id}$.

326 Id.

327 Bilaterals.org, China Calls for Expediting Free Trade Agreement, http://www.bilaterals.org/article.php3?id_article $=2453$.

328 Id.

329 See Cheow, supra note 323.

330 Bilaterals.org, supra note 327.

331 See Study Starts on Free Trade Zone for East Asia, CHINA DAILY, Jan. 24, 2005, http://www.chinadaily.com.cn/english/doc/2005-01/24/content_411515.htm.

332 Id.

333 Id.

334 Id. 
the European Union, and other Western nations and developed economies.

The termination of the ATC, and the potential resulting global economic crisis, enhanced the anticipated welfare-reducing effect of the proposed ASEAN-China FTA. ${ }^{335}$ This presents an issue of the need for a buffer, albeit seemingly contradictory to free trade, sanctioning trade distortions such as non-tariff barriers (NTBs) in the interests of the global economy. It is perhaps a matter of choosing the lesser of two evils. The choices are prospective and immeasurable trade distortions from an ASEAN-China FTA versus more quantitative trade distortions implicitly allowed to exist, if not legalized, under the WTO rules.

Ten years after the Uruguay Round multilateral trade negotiations, many subsidies and trade distortions remain. In terms of the implicitly legalized trade distortions, there is Article $\mathrm{XX}$ (b) of the GATT, which permits an importing country to introduce measures necessary to protect human, animal, or plant life and health. ${ }^{336}$ Furthermore, the WTO Agreement on Technical Barriers to Trade governs the imposition of technical requirements on products by an importing country. ${ }^{337}$ These include trade taxescum-subsidies, protection measures such as anti-dumping regulatory standards and domestic production subsidies. ${ }^{338}$ In addition, insufficient or excessive taxation or quantitative regulations also lead to inefficiencies and can be trade distorting. ${ }^{339}$ Most importantly, FTAs motivated by political considerations, which are legal pursuant to WTO rules, and proposed buffers such as NTBs to offset trade distortion, tend to produce trade and investment diversion rather than creation. ${ }^{340}$

335 ATC, supra note 23.

336 See Willy Lin, Chairman, Hong Kong Shipper's Council, Speech at the Pacific Economic Cooperation Council's 15th General Meeting: Implications of the End of the WTO Agreement on Textiles and Clothing, (Sept. 1, 2003), http://www.tdctrade.com/ shippers/vol26_5/vol26_5_chairman_03.htm; see also Joel P. Trachtman, Decisions of the Appellate Body of the World Trade Organization European Communities-Measures Affecting Asbestos and Asbestos-Containing Products, 12 EUR. J. INT'L L. 793 (2001), http://www.ejil.org/journal/curdevs/sr 13.html\#TopOfPage (discussing Article XX(b)).

337 See Lin, supra note 336.

338 See Anderson, supra note 276, at 2.

339 Id.

340 McKibbin \& Woo, supra note 232, at 6-11. 
Most problematic and discerning is that the ASEAN-China FTA, taken in conjunction with termination of the ATC, could produce immeasurable welfare-reducing effects and thus cause disastrous economic and social consequences worldwide.

One might argue that the 2004 ASEAN-China accord may not establish a trade region that is welfare reducing. In such an instance, it would create a trade region with a net static welfare gain; that is, trade and investment creation and not diversion. However, most ASEAN economies have not yet fully made the transition from food, agriculture, and forestry, to industrial development and export-based growth. ${ }^{341}$ Although developing rapidly, most ASEAN economies are still heavily dependent on agriculture and other food-based industries. ${ }^{342}$ ASEAN is still a relatively weak economic body. Notwithstanding the East Asian financial crisis, "[i]n 1999-2000, the region showed some signs of economic recovery but was interrupted by poor export performance and low FDI inflows. The September 11 incident further worsened conditions in the region, by causing economic slowdowns in ASEAN's major trading and investment partnersthe US, Japan and the European Union."343 In 2001, Intra-ASEAN exports accounted for only twenty percent of ASEAN's total exports, the same proportion as in $1970 .{ }^{344}$ ASEAN nations are still addressing a post-East Asian financial crisis of declining FDI. Moreover, non-market-led cooperative regionalism, rather than market-led cooperative regionalism, motivated an ASEAN-China FTA. $^{345}$ As a result, and reflecting orthodox trade theory, a proposed ASEAN-China FTA should not manifest a net static gain.

While China followed a trend in growing regionalism similar

341 Second ASEAN State of the Environment Report 2000, Chapter 4: Economic Development, 2000 UNEP RRC.AP, 24-37 (2000), http://www.rrcap.unep.org/subregion/aseansoe/.

342 Id.

343 Teofilo C. Daquila, Asean's Economic Performance Reviewing the Past, Looking to the future, 6(2) HARV. AsIA Q. 10 (2002), http://www.fas.harvard.edu 1 asiactr/haq/200203/daquila.pdf.

344 Walden Bello, Viewpoint: Is ASEAN Irrelevant?, PHILIPPINE DAILY INQUIRER, Dec. 17, 2004, http://www.bilaterals.org/article.php3?id_article=1060 (discussing problems of ASEAN regionalism).

345 Lijun, supra note 7; Baldwin, supra note 7; Cheow, supra note 323. 
to the European Union model, it nonetheless produced a variant model. China's model of regionalism is primarily motivated by political considerations, rather than economic considerations. The 2004 ASEAN-China Accord proposes a regionalism best described as non-orthodox and non-market-led cooperative regionalism. Given that the 2004 ASEAN-China Accord proposes the world's largest FTA, in conjunction with potential harm from the termination of the ATC, one can reasonably prognosticate both an enhanced trade distortion and welfare reducing effect. Assuming the pending 2004 ASEAN-China Accord creates trade diversion rather than trade creation, it is a threat to trade and investment liberalization, the goals of the WTO, and multilateral trade.

The problem of the trade creation-diversion dichotomy is that even FTAs based on the European Union model manifest some degree of trade diversion. However, such FTAs are motivated in part by political considerations that do not appear to threaten multilateral trade and count as examples the European Union and NAFTA. The WTO rules governing FTAs (Article XXIV) are in dire need of reform. In the interim, the ambiguities contained within both Article XXIV and the WTO Memorandum of Understanding on Article XXIV create implicitly legalized trade distortions, which contribute to both a growth of regionalism and an increase in threats to multilateral trade, such as the proposed ASEAN-China FTA.

Generally, the WTO is perceived as a free trade institution. However, in practical terms, it is more aptly described as an institution manifesting rules that do not actually prescribe free trade; instead, various substantive and procedural norms prescribe a code of conduct that makes trade a multilateral issue. ${ }^{346}$ As a result, the WTO is more of a rules-based system dedicated to open, fair, and undistorted competition. ${ }^{347}$ The latter is a more accurate descriptor of the WTO because WTO rules permit tariffs and other forms of protectionism or NTBs, such as anti-dumping. Such competition makes more obvious the problems of an

346 Killion, supra note 105 , at 53-56 (discussing free trade and multilateralism versus unilateralism).

347 Regionalism, Multilateralism, and the Politics of Global Trade, supra note 318 , at 33 . 
ambiguous and contradictory Article XXIV and evolving exceptions to Article XXIV become more obvious. Thus, pursuant to goals of open, fair, and undistorted competition, greater significance attaches to the issue of the threat of a proliferation of trade distorting FTAs, such as the proposed 2004 ASEAN-China FTA.

In this respect, the proposed ASEAN-China FTA may be a symptom of the problem of the WTO rules as opposed to the cause or justification for a seemingly growing preference of regionalism over multilateralism, particularly in the Asian region. Simply amending Article XXIV and lending clarity to its supposed proscriptions would stay the potential threat of regionalism. In terms of the WTO, the earlier mentioned interwar concerns are no longer relevant, justifying a departure from an intentional vagueness manifest in Article XXIV and the WTO Memorandum of Understanding on Article XXIV. The changing political economy of a post-WTO world and growing regionalism equally justify a departure from the inherent vagueness of Article XXIV.

However, this does not alleviate the potential threat of the 2004 ASEAN-China Accord. An OEDC study foretold that China's growth is losing its dynamism. ${ }^{348}$ Assuming this prediction is true, China should pursue more orthodox or even Western models of development. A case in point is the 1997-1998 East Asian financial crisis. ${ }^{349}$ This crisis brought into question whether too much had initially been expected from Asian industrialization or whether the Asian development model, in relying on foreign capital, lacked substance. ${ }^{350}$ Debates ensued concerning reaction to the Asian financial crisis and to the correctness of the IMF's prescription, especially what Asian economies deemed rigorous conditionalities of the IMF and World

348 Developments in Selected Non-member Economies, supra note 141.

349 Quaker United Nations Office, Convergence or Surrender on Development? The UN and Brentwood Institutions (QUNO Briefing Paper No. 2/00, Aug. 2000), http://www.afsc.org/quno/Resources/BP200008.htm ("Much of the blame for the 1998 financial crisis and its consequences has been placed with national governments but the IMF has also been faulted for initial misdiagnoses and for prescribing inappropriate solutions that worsened the crisis and its effects.").

350 See Takeshi Isayama, Comm'r, Japan Patent Office, Keynote Speech: APEC Region Intellectual Property Right Protections Beyond the Year 2000, 2 (Feb. 22, 1999), http://www.jpo.go.jp/shiryou_e/kovenroko_e/19990222.htm. 
Bank. ${ }^{351}$ There was also the problem of an influx of international short-term capital. ${ }^{352}$ During this period, the United States, Europe and Japan were criticized for doing too little, too late. ${ }^{353}$ The East Asian financial crisis left the Asia-Pacific region feeling the brunt of uncertainty, especially about the future. ${ }^{354}$ The East Asian financial crisis has been described as Asian economies forgetting to steadfastly pursue an industrialization pattern reflective of Asian reality. ${ }^{355}$ Asian economies depended on international short-term capital via financial liberalization to combat capital shortages. ${ }^{356}$ If Asian economies had developed their soft infrastructures, such as human resources, along with hard infrastructures, such as roads, factories, and transportation, then pursued a more orthodox industrial development path of cultivating industries, this problem would have never intensified to the degree that it did. ${ }^{357}$

The assessments of the East Asian financial crisis have been mixed. Some have argued that export orientation was the major source of growth competitiveness. ${ }^{358}$ However, one source challenged such findings through quantitative analysis of case studies and concluded that imports do have a stronger effect on productivity than exports. ${ }^{359}$ The ramification of the latter study directly relates to the 2004 ASEAN-China Accord because of the consequences of China's polity restricting imports or import-based growth via Chinese regionalism. Such regionalism is prompted by political considerations rather than economic considerations. As previously mentioned, in terms of imports, FTAs between aligned developing economies and the poorest economies, such as the

351 Id.

352 Id.

353 Id

354 Id.

355 Isayama, supra note 350.

356 Robert Z. Lawrence \& David E. Weinstein, Trade and Growth: Import-Led or Export-Led? Evidence from Japan and Korea, in RETHINKING THE EAST ASIA MIRACLE 379-407 (Joseph E. Stiglitz et. al. eds., 2001); see also HuiJIONG, supra note 129, at 327 338 (discussing earlier publications on East Asia's success).

357 Lawrence \& Weinstein, supra note 356, at 379-407.

358 See id.

359 See id. 
proposed ASEAN-China FTA, have a proclivity to generate trade diversion rather than trade creation. ${ }^{360}$ Notwithstanding proclivity of trade diversion stemming from aligned developing economies and termination of the ATC, a restriction on imports by the world's largest proposed FTA will produce and enhance both trade diversion and the resulting welfare-reducing effect. As a result, the 2004 ASEAN-China Accord proposes a non-orthodox and non-market-led cooperative regionalism, which will adversely affect trade and investment liberalization, the goals of the WTO, and the global economy.

Regionalism may constitute the movement of polities in terms of politics, rather than economies in terms of globalization. ${ }^{361}$ Assuming arguendo the latter is true, then regionalism is compromised in its capacity as a supposed complement to a multilateral trade approach. Indeed, the loophole for FTAs under WTO Rule XXIV and the WTO Memorandum of Understanding on Article XXIV needs to be closed by way of amendment. Otherwise, global trade may witness a continuing growth of FTAs and RTAs posing a threat to multilateral trade and allowed to flourish under the sanctuary of WTO rules that tolerate implicitly legalized trade distortion. Moreover, notwithstanding an amendment of Article XXIV, implicitly legalized trade distortion may evolve into explicitly legalized trade distortion, further enhancing threats to multilateral trade. In terms of amending the WTO rules, the critical issue is ascertaining the line between models of regionalism that complement multilateral trade and models of regionalism so "distortionary" in nature that the international trading system should no longer tolerate them.

Conversely, it may be that nations have acted politically, in pursuance of national and regional interests, as a dual approach to development, seeking both to liberalize and define the terms of their liberalization. ${ }^{362}$ However, to suggest China's leaders elected to pursue a dual approach in regionalism to complement a multilateral trade approach is a denial of China's solely political motivations in deciding to use FTAs as a political policy tool by directing the focus towards ASEAN becoming China's first FTA

360 McKibbin \& Woo, supra note 232, at 6-11.

361 See Bowles, supra note 223.

362 Id. 
partner. A problem for multilateral trade may well be China's ambition to politically dominate the Asian region. In terms of the survival of China's polity, China's political unilateral nationalistic concerns may override multilateral trade concerns. As a result, a trend in Chinese regionalism motivated by political considerations may increasingly manifest closed and unilateral models of regionalism, such as the proposed ASEAN-China FTA.

This article admittedly seeks to prospectively address a pending global trade crisis. The initial crisis is the trade diversion and welfare-reducing effect that will be produced by the world's largest FTA, the 2004 ASEAN-China Accord. The general theory of the welfare effect of trade distortion prognosticates a threat to multilateral trade, especially due to aligned developing economies in an FTA and restrictions on import-based growth. In addition, the threat to global trade from the 2004 ASEAN-China Accord is enhanced by the possibility of a future "JACIK" FTA. Further increasing the threat to multilateral trade is the timing of the accord. The 2004 ASEAN-China Accord concluded in November of 2004, just one month short of the termination of the ATC, therefore further enhancing the threat to multilateral trade.

\section{Conclusion}

Those entrusted with the responsibility of safeguarding multilateral trade and the goals and aspirations embodied in the WTO should follow closely China's growing regionalism (quyu zhuyi). An Asian Development Bank (ADB) study, conducted in terms of the emergence of China, observed that China "presents as many opportunities as threats to East Asian policy makers." 363 The study also noted that including China in ASEAN could induce trade diversion across both the region and "with respect to economies outside East Asia." 364 Primarily due to sheer size, China "appears to be in a unique position to 'go it alone' on the path to globalization, i.e. most of its own benefits from multilateralism can be captured by unilateral liberalization." ${ }^{\text {365 }}$ An

363 See David Roland-Holst, An Overview of PRC's Emergence and East Asian Trade Patterns to 20204 (ADB Institute, Research Paper Series No. 44, Oct. 2002), available at http://www.adbi.org/research-paper/2002/10/01/90.prc.s.emergence/.

364 Id.

365 Id. at 4. 
exclusionary model of Chinese regionalism, such as the proposed ASEAN-China FTA, motivated by political considerations, constitutes unilateralism in trade and poses a threat to multilateral trade.

The success of the 2004 ASEAN-China Accord would represent a new model of regionalism in that it is an alignment of developing economies and contradicts orthodox and conventional wisdom of both import-based growth and Western models of regionalism. Moreover, a successful ASEAN-China FTA, in conjunction with a China-led "JACIK" FTA, both motivated by political considerations, presents a serious threat to trade and investment liberalization, multilateral trade, and the goals of the WTO. Notwithstanding an amendment to WTO Article XXIV, the multilateral world trading system may someday awake and find itself the victim of the dynamics of China's sheer size and unilateral regionalism. 
